\title{
Indigenous uses of ethnomedicinal plants among forest-dependent communities of Northern Bengal, India
}

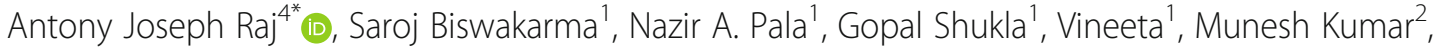
Sumit Chakravarty ${ }^{1}$ and Rainer W. Bussmann ${ }^{3}$

\begin{abstract}
Background: Traditional knowledge on ethnomedicinal plant is slowly eroding. The exploration, identification and documentation on utilization of ethnobotanic resources are essential for restoration and preservation of ethnomedicinal knowledge about the plants and conservation of these species for greater interest of human society.

Methods: The study was conducted at fringe areas of Chilapatta Reserve Forest in the foothills of the eastern sub-Himalayan mountain belts of West Bengal, India, from December 2014 to May 2016. Purposive sampling method was used for selection of area. From this area which is inhabited by aboriginal community of Indo-Mongoloid origin, 400 respondents including traditional medicinal practitioners were selected randomly for personal interview schedule through open-ended questionnaire. The questionnaire covered aspects like plant species used as ethnomedicines, plant parts used, procedure for dosage and therapy.

Results: A total number of 140 ethnomedicinal species was documented, in which the tree species (55) dominated the lists followed by herbs (39) and shrubs (30). Among these total planted species used for ethnomedicinal purposes, 52 species were planted, 62 species growing wild or collected from the forest for use and 26 species were both wild and planted. The present study documented 61 more planted species as compared to 17 planted species documented in an ethnomedicinal study a decade ago. The documented species were used to treat 58 human diseases/ailments including nine species used to eight diseases/ailments of domestic animals. Stomach-related problems were treated by maximum number of plants (40 species) followed by cuts and wounds with 27 plant species and least with one species each for 17 diseases or ailments. Maximum number of 12 diseases/ailments was cured by Melia azedarach followed by Centella asiatica and Rauvolfia serpentina which were used to cure 11 diseases/ailments each.

Conclusions: The list of 140 plant species indicates that the Chilapatta Reserve Forest and its fringe areas are rich in biodiversity of ethnobotanical plant species. Rauvolfia serpentina were the most valuable species in terms of its maximal use with higher use value. The documentation of 78 species maintained in the home gardens indicates the community consciousness on the conservation values of these ethnobotanical species. The communities should be encouraged with improved cultivation techniques of commercially viable ethnobotanical species through capacity building, timely policy intervention along with strong market linkage. This will ensure income generation and livelihood improvement and ultimate conservation of these species.
\end{abstract}

Keywords: Tradition, Indigenous, Disease, Liver, Policy

* Correspondence: drajr.aaidu@gmail.com

${ }^{4}$ Mekelle University, Mekelle, Tigray, Ethiopia

Full list of author information is available at the end of the article 


\section{Background}

Due to globalization and green revolution, natural resources are rapidly dwindling due to the unsustainable anthropogenic activity. Consequently, the primary challenge to human society is the steady change in climate, reduction in biodiversity and dependence on external resources without giving emphasis on the enriched localised natural resources. In this setting, there is a need to explore the indigenous knowledge base for ecological, economic and environmental sustainability. Especially, forest fringe communities are associated with the forest for maintaining their livelihoods. Use of medicinal plants to treat various diseases has been part of human culture since ancient times [1]. Botanically derived medicinal plants play a major role in human society [2]. Traditional medicine forms a valuable resource for the development of new pharmaceuticals [3]. The exploration, utilization and conservation of these ethnobotanic resources are essential for restoration and preservation of traditional and indigenous knowledge $[4,5]$. This acquired knowledge about the plants is very essential to be used in the near future [6]. Moreover, in developing countries now, the trend is to incorporate traditional medicines in local healthcare system and interest has increased among the researchers to explore the huge potential of ethnomedicinal knowledge for treating various diseases $[7,8]$.

In India and particularly in West Bengal people living in remote and rural localities are still dependent on traditional medicines for treatments of various ailments [9-12]. Indigenous people of Indo-Mongoloid origin inhabiting Chilapatta Reserve Forest in northern part of West Bengal are still using forest-originated products for their healthcare needs due to lack of availability of modern medical facilities and poor socio-economic condition [10]. The tendency of disinterestedness in old traditions is feared by elders as a major cause of losing this wealth of knowledge in coming time soon. Since traditional knowledge on ethnomedicinal plant is being eroded through acculturation and the loss of plant biodiversity along with indigenous people and their cultural background, hence, promoting research on these plants is crucial in order to safeguard this information for future societies for sustainable use and their conservation $[13,14]$.

Ethnomedicinal surveys provide data and information basis for conservation and sustainable utilization of local wild plants and also contribute to preserve cultural and genetic diversity. No new plant product, particularly wild, will be accepted by the urban population without proper testimony from specialists. The present study was therefore undertaken in the forest fringe area of Chilapatta Forest of West Bengal having objectives (i) document the ethnomedicinal plant species used by the community, (ii) tradition medicinal use and pattern and (iii) comparison of reported uses with different publications.

\section{Methods}

\section{Study area}

The present study was carried out at the forest fringe villages of Chilapatta Reserve Forest located in the subHimalayan mountain belts of West Bengal, India. The forest spreading over $41 \mathrm{~km}^{2}$ lies within the jurisdiction of Cooch Behar Wildlife Division in Alipurduar district (Fig. 1b). The forest is about $30 \mathrm{~km}$ away both from Cooch Behar and Alipurduar town, headquarters of Cooch Behar and Alipurduar district, and is transected by National Highway no. 31C. The fringe villages are Uttar Simlabari, Uttar Chaukakheti, Andu Basty, Bania Basty, Dakshin Mendabari, Uttar Mendabari, Kodal Basty, Kurmai Basty and Chilapatta Kumarpara. The elevation of the working site as measured by GPS (Garmin 72) was latitude $26^{\circ} 32.85^{\prime} \mathrm{N}$ and longitude $89^{\circ} 22.99^{\prime} \mathrm{E}$. Mean altitude of the area was $47 \mathrm{~m}$ above MSL. The region is sub-tropical receiving average annual rainfall of $250-300 \mathrm{~cm}$ from south-west monsoon of which $80 \%$ is received from June to August. The summer and winter temperature are mild with $34{ }^{\circ} \mathrm{C}$ as the highest in the month of May while the lowest temperature is $7.5{ }^{\circ} \mathrm{C}$ during January. The forest villages with around 1000 households (average family size of 5-7 members) are inhabited by local communities of Indo-Mongoloid origin, including the Raj Bangshis, Mech, Ravas, Totos, Limbus, Lepchas, Nageshias, Uraons and Mundas. These fringe communities of the Chilapatta Reserve Forest are economically disadvantaged and thus depend on the forest and subsistence farming for their livelihoods.

\section{Ethnobotanical data collection}

The study was conducted from December 2014 to May 2016. The villages selected were purposive. An exhaustive list of households in each village was prepared with the active cooperation of State Forest Department and local village administration ('Panchayat'). Prior informed consent and permission to interview the villagers was obtained from the village administration and each participant verbally. A pre-tested open-ended personal interview schedule was used to elucidate aspects like plant species used as ethnomedicines, plant parts used, procedure for dosage, diseases treated and therapy. Field surveys were conducted for collecting information through interviews. Only participants over 30 years of age were considered as respondents. The age of a person was reported significantly effecting traditional knowledge [15]. Thus, a total number of 400 respondents including traditional medicinal practitioners were selected randomly. Among the respondents, 91\% were males. Females did not responded to our questionnaire without their male folk; and so only those female respondents were considered who responded independently. Fortynine per cent of the respondents were in the age range 


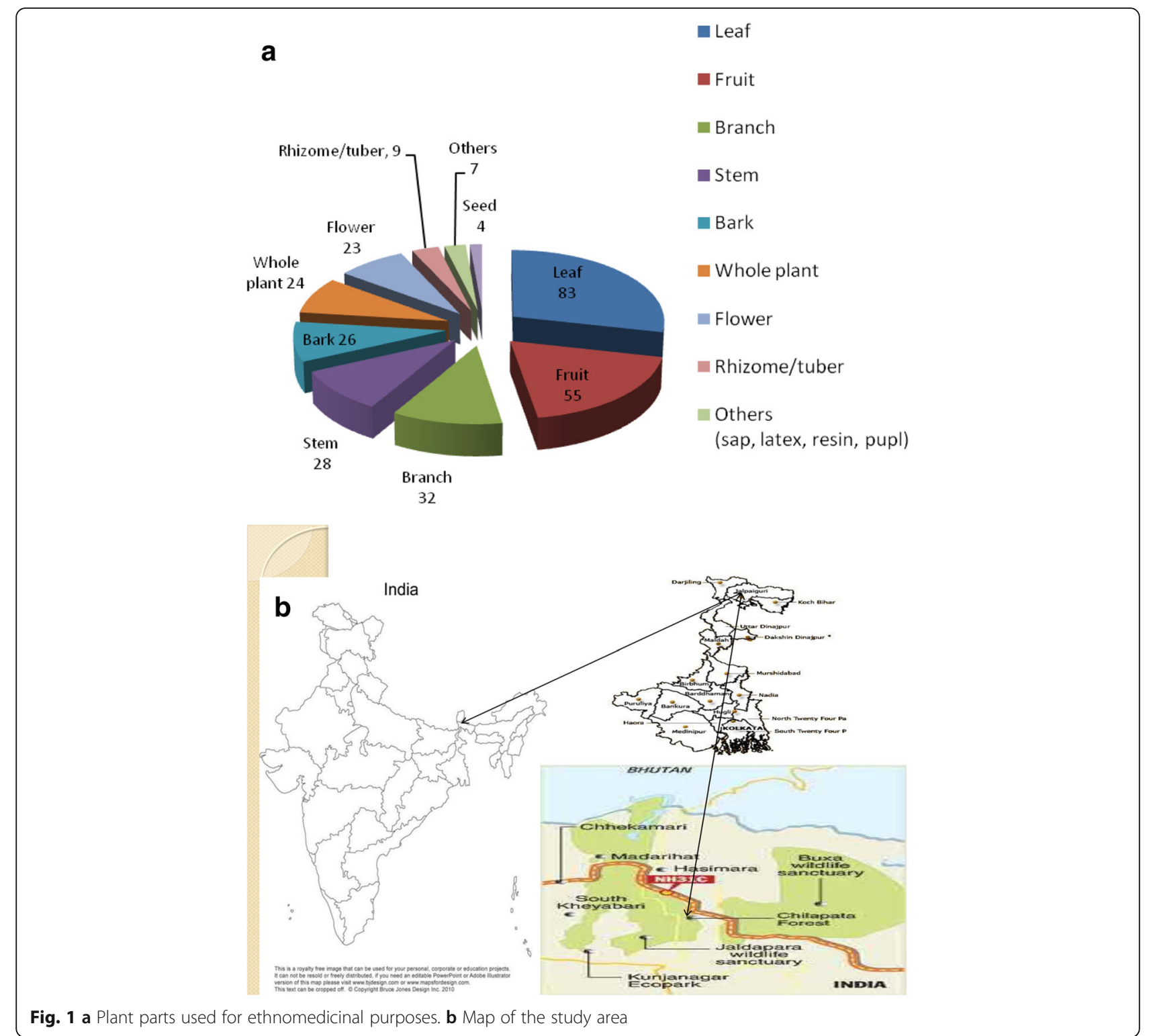

of $33-52$ years, $39 \%$ in range of $53-72$ years and $12 \%$ in the range of 73-92 years. Majority of the respondents (71\%) have attended school up to primary level or more. The schedule was administered to the respondent in local language, and the responses were recorded in English on the schedule.

The plant specimens were collected during the survey with the help of respondents. The specimens were mounted on herbarium sheets and were identified with the herbariums of Department of Forestry, Uttar Banga Krishi Viswavidyala, Pundibari, and Department of Botany, North Bengal University, Siliguri, West Bengal. The collected information on the ethnomedicinal plants was also cross checked with published available literature. For each species, the use value (UV), as adapted by [16] from the proposal of [17], was calculated. This quantitative method evaluates the relative importance of each medicinal species based on its relative use among informants. Use value is estimated as $U / n$, where $U$ is the number of times a species is cited and $n$ is the number of informants. The use value of each species is therefore based objectively on the importance attributed by the informants and does not depend on the opinion of the researcher [16]. The collected data were analysed by using Microsoft Excel.

\section{Results and discussion}

Ethnomedicinal richness

A total number of 140 ethnomedicinal species represented by 116 genera and 65 families used by the indigenous communities dwelling in the fringe areas of Chilapatta Reserve Forest were documented (Table 1). Out of these, 139 species were plants and one was fungus (Ganoderma 
Table 1 List of documented ethnobotanic plants used by the communities living in fringe villages of Chilapatta Reserve Forest

\begin{tabular}{|c|c|c|c|c|c|c|c|}
\hline 1 & 2 & 3 & 4 & 5 & 6 & 7 & 8 \\
\hline \multirow[t]{3}{*}{ Acanthaceae } & $\begin{array}{l}\text { Andrographis paniculata (Burm.f.) } \\
\text { Wall. ex Nees }\end{array}$ & Kalmegh, Chirawta & 0.03 & $\mathrm{H}$ & $S p^{*}$ & $\mathrm{PI}$ & $M, R$ \\
\hline & Justicia adhatoda L. & Basakpatta & 0.05 & S & $S p^{*}$ & W & $\mathrm{M}, \mathrm{O}, \mathrm{Cr}$ \\
\hline & Justicia gendarussa Burm. f. & Bishalyokoroni & 0.02 & S & & W & $M, B$ \\
\hline Acoraceae & Acorus calamus $\mathrm{L}$. & Ghorbaj Vasa bach, bojho & 0.02 & $\mathrm{H}$ & $S p^{*}$ & PI & $\mathrm{M}, \mathrm{Cr}$ \\
\hline Amaranthaceae & Alternanthera brasiliensis (L.) Kuntze & Lalful, Itingjhar & 0.03 & $\mathrm{H}$ & & $\mathrm{PI} / \mathrm{W}$ & $\mathrm{O}, \mathrm{N}$ \\
\hline Amaryllidaceae & Urginea indica (Roxb.) Kunth & Janglipiyaz & 0.01 & $\mathrm{H}$ & & W/PI & $\mathrm{O}$ \\
\hline Anarcardiaceae & Mangifera indica L. & Amba & 0.05 & $\mathrm{~T}$ & & PI & $\mathrm{O}, \mathrm{Ck}$ \\
\hline Annonaceae & Annonas squamosa $\mathrm{L}$. & Atafol, Saripha & 0.01 & $\mathrm{~T}$ & & PI & O \\
\hline \multirow[t]{3}{*}{ Apiaceae } & Anethum graveolens $\mathrm{L}$. & Soya sag & 0.01 & $\mathrm{H}$ & & $\mathrm{Pl}$ & R \\
\hline & Centella asiatica (L.) Urb. & Bang Sag, Thankuni, Gortapre & 0.13 & $\mathrm{H}$ & $\mathrm{Co}^{*}$ & W & $\mathrm{M}, \mathrm{O}, \mathrm{Ck}, \mathrm{N}, \mathrm{B}$ \\
\hline & $\begin{array}{l}\text { Centella annua } \\
\text { M. Schub. \& B.-E. van Wyk }\end{array}$ & Mana-muni, Beng sag & 0.04 & $\mathrm{H}$ & & W & $\mathrm{M}, \mathrm{O}, \mathrm{B}$ \\
\hline \multirow[t]{5}{*}{ Apocynaceae } & Alstonia scholaris (L.) R. Br. & Chatian & 0.04 & $\mathrm{~T}$ & $\mathrm{Fr}^{*}, \mathrm{Sp}^{* *}$ & W/PI & $\mathrm{M}, \mathrm{O}$ \\
\hline & Calotropis procera (Aiton) R. Br. & Akhanda, Akwanpata & 0.02 & S & & $\mathrm{Pl}$ & $R, B$ \\
\hline & Rauvolfia serpentine (L.) Benth ex Kurz. & Nakbail, Sarpaganda & 0.11 & $\mathrm{H}$ & $E^{*}$ & $\mathrm{PI} / \mathrm{W}$ & $\mathrm{M}, \mathrm{R}, \mathrm{O}, \mathrm{Cr}, \mathrm{N}$ \\
\hline & $\begin{array}{l}\text { Tabernaemontana divaricata (L.) } \\
\text { R. Br. ex Roem. \& Schult. }\end{array}$ & Baramasheful, Setoful, Tagarful & 0.02 & S & $\mathrm{R}^{* *}$ & W & $\mathrm{O}, \mathrm{N}$ \\
\hline & Thespesia populnea (L.) Sol. ex Corrêa & Kanaliful, Karabiful & 0.01 & $\mathrm{~S}$ & & $\mathrm{Pl}$ & Ck \\
\hline Araceae & Colocasia esculenta (L.) Schott & Ban-kachu & 0.01 & $\mathrm{H}$ & $S p^{* *}$ & $\mathrm{PI} / \mathrm{W}$ & $\mathrm{R}$ \\
\hline \multirow[t]{3}{*}{ Arecaceae } & Areca catechu L. & Supari, Goi) & 0.03 & $\mathrm{~T}$ & & $\mathrm{Pl}$ & $\mathrm{R}, \mathrm{N}$ \\
\hline & Cocos nucifera $\mathrm{L}$. & Nariyal, Narkel & 0.02 & $\mathrm{~T}$ & & $\mathrm{Pl}$ & $\mathrm{R}$ \\
\hline & Phoenix sylvestris (L.) Roxb. & Khejur & 0.01 & $\mathrm{~T}$ & & W & $\mathrm{O}$ \\
\hline Asclepiadaceae & Hemidesmus indicus (L.) R. Br. & Anantamul & 0.01 & $\mathrm{H}$ & & W & M \\
\hline Asparagaceae & Asparagus racemosus Willd. & Satomuli, Satalu & 0.03 & $\mathrm{H}$ & $\mathrm{Pl}^{*}$ & PI & $\mathrm{M}, \mathrm{O}$ \\
\hline \multirow[t]{4}{*}{ Asteraceae } & $\begin{array}{l}\text { Ageratina adenophora (Spreng.) } \\
\text { R.M. King \& H. Rob. }\end{array}$ & Banmara, German gach, Asamiapatta & 0.04 & $\mathrm{~S}$ & $A^{*}$ & W & $\mathrm{M}, \mathrm{O}$ \\
\hline & Ageratum conyzoides L. & Uchanti, Bhusuripata, Elame & 0.01 & $\mathrm{H}$ & $A^{*}, R^{* *}$ & W & $\mathrm{O}$ \\
\hline & Eupatorium odoratumL. & Asamia, Banmara & 0.02 & S & $\mathrm{Fr}^{* *}$ & W & O \\
\hline & Tagetes erecta $\mathrm{L}$. & Mainalibibod, Marigold, Gendaful, Saipatri & 0.03 & $\mathrm{H}$ & & $\mathrm{Pl}$ & $\mathrm{O}, \mathrm{Ck}, \mathrm{N}$ \\
\hline Athyriaceae & Diplazium esculentum (Retz.) Sw. & Khukri, Dhekia sag, Niguro & 0.05 & $\mathrm{~F}$ & $S p^{* *}$ & W & R \\
\hline Bambucaceae & Bombax ceiba L. & Semul & 0.02 & $\mathrm{~T}$ & $S p^{*}, S p^{* *}$ & $\mathrm{PI} / \mathrm{W}$ & $\mathrm{R}$ \\
\hline Basellaceae & Basella alba $\mathrm{L}$. & Puin sag, Poi sag & 0.02 & C & & PI & O \\
\hline Bignoniaceae & Oroxylum indicum (L.) Kurz. & Kanaidingi, Totola, Surimala & 0.09 & $\mathrm{~T}$ & $\mathrm{Fr}^{*}, \mathrm{Sp}^{* *}$ & $\mathrm{PI} / \mathrm{W}$ & $\mathrm{R}, \mathrm{O}, \mathrm{N}, \mathrm{B}$ \\
\hline Brassicaceae & Brassica rugosa (Roxb.) L.H. Bailey & Raya sag & 0.01 & $\mathrm{H}$ & & $\mathrm{Pl}$ & R \\
\hline Bromeliaceae & Ananas comosus (L.) Merr. & Anaras, Bhuikathar & 0.02 & $\mathrm{H}$ & & PI & $\mathrm{M}, \mathrm{O}$ \\
\hline Cactaceae & Opuntia ficus-indicaHaw. & Sidhugach, Fanimanasa & 0.02 & $S$ & & $\mathrm{Pl}$ & O \\
\hline Caricaceae & Carica papaya $\mathrm{L}$. & Papita, Mewa & 0.03 & $\mathrm{~T}$ & & $\mathrm{Pl}$ & $\mathrm{M}, \mathrm{O}$ \\
\hline Chenopodiaceae & Chenopodium album L. & Bethu sag (N) & 0.01 & $\mathrm{H}$ & & W & M \\
\hline \multirow[t]{3}{*}{ Combretaceae } & $\begin{array}{l}\text { Terminalia arjuna } \\
\text { (Roxb. ex DC.) Wight \& Arn }\end{array}$ & Arjun & 0.09 & $\mathrm{~T}$ & & $\mathrm{PI} / \mathrm{W}$ & $\mathrm{M}, \mathrm{R}, \mathrm{O}, \mathrm{N}, \mathrm{Bi}$ \\
\hline & Terminalia bellirica (Gaertn.) Roxb. & Boir, Bahera, Barra & 0.06 & $\mathrm{~T}$ & $R^{*}, S p^{* *}$ & W & $\mathrm{R}, \mathrm{O}$ \\
\hline & Terminalia chebula Retz. & Haritaki, Harra & 0.09 & $\mathrm{~T}$ & $R^{*}, S p^{* *}$ & W & $\mathrm{M}, \mathrm{R}, \mathrm{O}, \mathrm{N}$ \\
\hline \multirow[t]{3}{*}{ Convolvulaceae } & Cuscuta europaea L. & Kankor, Pahelolahara & 0.01 & C & & W & $\mathrm{R}$ \\
\hline & Ipomoea batatas (L.) Lam. & Sakarkanda, Mistialu & 0.02 & $\mathrm{Cr}$ & & $\mathrm{Pl}$ & $\mathrm{O}$ \\
\hline & Ipomoea carnea Jacq. & Karmigach, Thater & 0.01 & $\mathrm{H}$ & & W & $\mathrm{O}$ \\
\hline
\end{tabular}


Table 1 List of documented ethnobotanic plants used by the communities living in fringe villages of Chilapatta Reserve Forest (Continued)

\begin{tabular}{|c|c|c|c|c|c|c|c|}
\hline 1 & 2 & 3 & 4 & 5 & 6 & 7 & 8 \\
\hline Crassulaceae & Bryophyllum pinnatum (Lam.) Kurz. & Patharkuchi & 0.01 & $\mathrm{H}$ & & $\mathrm{PI}$ & B \\
\hline \multirow[t]{5}{*}{ Cucurbitaceae } & Coccinia coridifolia (L.) Cogn. & Kundri & 0.01 & C & & W & $\mathrm{O}$ \\
\hline & Coccinia indica Wight \& Arn. & Kundli, Telakuchu & 0.01 & C & & $\mathrm{Pl}$ & $\mathrm{O}$ \\
\hline & Lagenaria siceraria (Molina) Standl. & Lou & 0.01 & C & & $\mathrm{Pl}$ & $\mathrm{O}$ \\
\hline & Luffa aegyptiaca Mill. & Gongra, Dhudol, Gherawla & 0.01 & C & & W & O \\
\hline & Momordica diocia Roxb. & Jangli karela, Ban karola & 0.02 & C & $\mathrm{Co}^{*}$ & W & $\mathrm{R}, \mathrm{O}$ \\
\hline Dilleniaceae & Dillenia indica $\mathrm{L}$. & Pachkol (chalta) & 0.07 & $\mathrm{~T}$ & $S p^{* *}$ & W & $M, R, O$ \\
\hline \multirow[t]{2}{*}{ Dioscoreaceae } & Dioscorea belophylla Voigt & $\begin{array}{l}\text { Janglialu, Ban alu, Gichikanda, } \\
\text { Ghetuallu }\end{array}$ & 0.05 & C & $\mathrm{R}^{* *}$ & W & $\mathrm{R}, \mathrm{O}, \mathrm{Ck}$ \\
\hline & Dioscorea bulbifera L. & Kowatumbil & 0.01 & C & & W & $\mathrm{O}$ \\
\hline Diptrocarpaceae & Shorea robusta Gaertn. & Sal & 0.09 & $\mathrm{~T}$ & $\mathrm{Sp}^{*}, \mathrm{Fr}^{* *}$ & W & $\mathrm{R}, \mathrm{O}$ \\
\hline Elaeocarpaceae & Elaeocarpus ganitrusRoxb. ex G. Don & Rudrax & 0.01 & $\mathrm{~T}$ & $E^{1}$ & W & N \\
\hline \multirow[t]{8}{*}{ Euphorbiaceae } & Baccaurea ramiflora Lour. & Notko, Latkafal & 0.02 & $\mathrm{~T}$ & & $\mathrm{PI} / \mathrm{W}$ & $\mathrm{R}$ \\
\hline & $\begin{array}{l}\text { Baccaurea sapinda } \\
\text { (Roxb.) Müll. Arg. }\end{array}$ & Kusum & 0.02 & $\mathrm{~T}$ & & $\mathrm{PI} / \mathrm{W}$ & $\mathrm{M}, \mathrm{O}$ \\
\hline & Codiaeum variegatum (L.) Blume & Pattabahargach & 0.01 & S & & $\mathrm{Pl}$ & $\mathrm{O}$ \\
\hline & Emblica officinalis Gaertn. & Amlai, Amla, Amloki & 0.03 & $\mathrm{~T}$ & & $\mathrm{Pl}$ & $\mathrm{M}, \mathrm{N}, \mathrm{Bi}$ \\
\hline & $\begin{array}{l}\text { Hevea brasiliensis (Willd. ex A. Juss.) } \\
\text { Müll. Arg. }\end{array}$ & Loborgach & 0.01 & $T$ & & $\mathrm{Pl}$ & N \\
\hline & Jatropha curcas L. & Arandi, Bharenda & 0.02 & S & $S p^{*}$ & $\mathrm{Pl}$ & $\mathrm{M}, \mathrm{Cr}$ \\
\hline & Mallotus tetracoccus (Roxb.) Kurz. & Pethali & 0.01 & $\mathrm{~T}$ & & W & $\mathrm{O}$ \\
\hline & Ricinus communis $\mathrm{L}$. & Aranda,Varenda, Rahari & 0.03 & S & $S p^{* *}$ & W & $\mathrm{M}, \mathrm{O}$ \\
\hline \multirow[t]{12}{*}{ Fabaceae } & Acacia catechu (L. f.) Willd. & Khairgach & 0.01 & $\mathrm{~T}$ & $S p^{*}$ & W & $\mathrm{R}$ \\
\hline & Acacia nilotica (L.) Willd. ex Delile & Kadamkapurgach, Babul & 0.01 & $\mathrm{~T}$ & & W & O \\
\hline & Bauhinia malabarica Roxb. & Kanchan, Tanki, Karmai & 0.02 & $\mathrm{~T}$ & & $\mathrm{PI} / \mathrm{W}$ & $\mathrm{R}, \mathrm{N}$ \\
\hline & Cajanus cajan (L.) Huth & Rahar, Raheri & 0.03 & $S$ & & $\mathrm{Pl}$ & $\mathrm{M}, \mathrm{Ck}$ \\
\hline & Cassia alata $\mathrm{L}$. & Chakora & 0.03 & $S$ & & $\mathrm{PI} / \mathrm{W}$ & O \\
\hline & Cassia sophera L. & Choto-kalkasunda & 0.01 & $S$ & & $\mathrm{PI} / \mathrm{W}$ & M \\
\hline & Hippocrepis emerus (L.) Lassen & Heranchi & 0.01 & $\mathrm{~S}$ & & W & M \\
\hline & Mimosa pudica $\mathrm{L}$. & Lajjabati & 0.01 & $\mathrm{H}$ & $\mathrm{Fr}^{*}, \mathrm{R}^{* *}$ & W & $\mathrm{R}$ \\
\hline & Pongamia pinnata (L.) Merr. & Karanj & 0.01 & $\mathrm{~T}$ & & $\mathrm{PI} / \mathrm{W}$ & O \\
\hline & Tamarindus indica $\mathrm{L}$. & Tetul, Tittri & 0.01 & $\mathrm{~T}$ & $S p^{*}$ & $\mathrm{Pl}$ & $\mathrm{Ck}$ \\
\hline & Entada rheedii Spreng. & Gila, Gilathakuri & 0.01 & $\mathrm{~T}$ & $S p^{*}$ & W & M \\
\hline & Trigonella foerum L. & Methi & 0.01 & $\mathrm{H}$ & & $\mathrm{Pl}$ & $\mathrm{O}$ \\
\hline Fagaceae & Quercus castanopsis H. Lev & Guras & 0.01 & $\mathrm{~S}$ & & W & M \\
\hline Ganodermataceae & Ganoderma lucidum (Curtis) P. Karst. & Kath mushroom & 0.02 & $\mathrm{Fn}$ & & W & O \\
\hline \multirow[t]{6}{*}{ Lamiaceae } & Clerodendrum viscosum Vent. & Bhauti, Dhatupatta, Ghentu, Bhatghato & 0.04 & $\mathrm{~S}$ & $S p^{* *}$ & W & $\mathrm{O}, \mathrm{Ck}, \mathrm{N}, \mathrm{B}$ \\
\hline & Gmelina arborea Roxb. ex. Sm. & Gamar & 0.01 & $\mathrm{~T}$ & $\mathrm{Fr}^{*}, \mathrm{Sp}^{* *}$ & $\mathrm{PI} / \mathrm{W}$ & $\mathrm{O}$ \\
\hline & Leucas aspera (Willd.) Link & Kanshisa, Ghuma, Thumbai & 0.08 & $\mathrm{H}$ & & W & $M, R, O$ \\
\hline & Ocimum sanctum $\mathrm{L}$. & Tulsi & 0.08 & $\mathrm{H}$ & & $\mathrm{PI}$ & $M, R, O, B$ \\
\hline & Cinnamomum camphora (L.) J. Presl & Dalchini & 0.01 & $\mathrm{~T}$ & & $\mathrm{PI} / \mathrm{W}$ & O \\
\hline & $\begin{array}{l}\text { Machilus villosa } \\
\text { (Roxb.) Hook. f. }\end{array}$ & Kawla & 0.01 & $\mathrm{~T}$ & $\mathrm{Fr}^{* *}$ & W & O \\
\hline Lecythidaceae & Careya arborea Roxb. & Kumbhi & 0.02 & $\mathrm{~T}$ & $\mathrm{Fr}^{* *}$ & $\mathrm{Pl}$ & $\mathrm{R}, \mathrm{O}$ \\
\hline Lythraceae & Lagerstroemia speciosa (L.) Pers. & Jarul & 0.01 & $\mathrm{~T}$ & $\mathrm{Fr}^{* *}$ & $\mathrm{PI} / \mathrm{W}$ & $\mathrm{R}$ \\
\hline
\end{tabular}


Table 1 List of documented ethnobotanic plants used by the communities living in fringe villages of Chilapatta Reserve Forest (Continued)

\begin{tabular}{|c|c|c|c|c|c|c|c|}
\hline 1 & 2 & 3 & 4 & 5 & 6 & 7 & 8 \\
\hline & Punica granatum L. & Darim, Bedana & 0.01 & $T$ & & $\mathrm{PI}$ & $M$ \\
\hline \multirow[t]{2}{*}{ Malvaceae } & Abroma augusta (L.) L.f. & Ulatkambal & 0.03 & S & $S p^{*}$ & W & $\mathrm{O}, \mathrm{Cr}$ \\
\hline & Hibiscus rosa sinensis L. & Pajatiful & 0.01 & S & & $\mathrm{Pl}$ & M \\
\hline Melastomataceae & Melastoma malabathricum L. & Datrangi & 0.01 & S & $\mathrm{R}^{* *}$ & W & O \\
\hline \multirow[t]{2}{*}{ Meliaceae } & Azadirachta indica A. Juss & Neemgach & 0.05 & T & $\left.\mathrm{P}\right|^{*}$ & $\mathrm{Pl}$ & $\mathrm{R}, \mathrm{O}, \mathrm{Ck}$ \\
\hline & Melia azedarach L. & Ghora neem, Bakain, Bakaina & 0.02 & $\mathrm{~T}$ & & $\mathrm{Pl}$ & $\mathrm{O}$ \\
\hline Menispermaceae & $\begin{array}{l}\text { Tinospora cordifolia (Willd.) } \\
\text { Miers ex Hook. f. \& Thom. }\end{array}$ & Gulancha & 0.01 & C & $\mathrm{E}^{*}, \mathrm{Fr}^{* *}$ & W & M \\
\hline \multirow[t]{9}{*}{ Moraceae } & Artocarpus hetrophyllus Lam & Kathal & 0.03 & $\mathrm{~T}$ & $\mathrm{Pl}^{*}$ & $\mathrm{Pl}$ & $\mathrm{R}, \mathrm{O}, \mathrm{Cr}$ \\
\hline & Artocarpus lakoocha Wall. ex Roxb. & Ban-kathal & 0.02 & $\mathrm{~T}$ & $S p^{*} ; \mathrm{Fr}^{* *}$ & $\mathrm{Pl} / \mathrm{W}$ & $\mathrm{R}$ \\
\hline & Ficus benghalensis $\mathrm{L}$. & Bar rukh & 0.01 & $\mathrm{~T}$ & & W & N \\
\hline & Ficus carica L. & Dumber & 0.01 & $\mathrm{~T}$ & & W & O \\
\hline & Ficus elmeri Merr. & Jog dumur & 0.01 & $\mathrm{~T}$ & & W & $\mathrm{R}$ \\
\hline & Ficus geniculata Kurz & Futkol, Kabragach, Pakri & 0.02 & T & & W & $\mathrm{R}, \mathrm{O}$ \\
\hline & Ficus hispida L. f. & Kuchuli & 0.01 & T & & W & $\mathrm{O}$ \\
\hline & Ficus racemosa $\mathrm{L}$. & Dumur & 0.02 & $\mathrm{~T}$ & & W & $\mathrm{O}, \mathrm{Cr}$ \\
\hline & Morus alba L. & Neel tuth, Tuth & 0.06 & $\mathrm{~T}$ & & $\mathrm{Pl}$ & $M, R, O$ \\
\hline Moringaceae & Moringa oleifera Lam. & Sajana & 0.06 & $\mathrm{~T}$ & $\mathrm{Co}^{*}$ & $\mathrm{Pl}$ & $M, R, O, N$ \\
\hline Musaceae & Musa balbisiana Colla & Kola & 0.08 & $\mathrm{H}$ & & $\mathrm{Pl}$ & $\mathrm{M}, \mathrm{R}, \mathrm{O}, \mathrm{Ck}, \mathrm{Cr}$ \\
\hline Myristicaceae & Myristica longifolia Wall. ex Blume & Raktakamal, Rakatgach & 0.03 & T & $S p^{* *}$ & W & $\mathrm{O}, \mathrm{Cr}, \mathrm{B}$ \\
\hline \multirow[t]{2}{*}{ Myrtaceae } & Psidium guajava $\mathrm{L}$. & Peyara, Asputai & 0.04 & $\mathrm{~T}$ & $\mathrm{Co}^{*}$ & $\mathrm{Pl}$ & $M, R, O$ \\
\hline & Syzygium cumini(L.) Skeels & Jamura, Jam, Jamur, Jamun & 0.02 & $\mathrm{~T}$ & $\mathrm{Fr}^{* *}$ & $\mathrm{Pl}$ & $\mathrm{R}$ \\
\hline Oleaceae & Nyctanthes arbor-tristis L. & Sefaliful & 0.02 & S & & $\mathrm{Pl}$ & $\mathrm{O}$ \\
\hline Oxalidaceae & Averrohoa carambola L. & Kamringa, Charpatay & 0.01 & $\mathrm{~T}$ & & $\mathrm{Pl}$ & $\mathrm{R}$ \\
\hline Piperaceae & Piper nigrum L. & Golmorich & 0.01 & C & & $\mathrm{Pl}$ & $\mathrm{Bi}$ \\
\hline Plumbaginaceae & Plumbago zeylanica L. & Chitwar & 0.03 & $\mathrm{~S}$ & $R^{*}$ & W & $\mathrm{M}, \mathrm{O}$ \\
\hline \multirow[t]{6}{*}{ Poaceae } & Arundo donax L. & Nolkhagra & 0.01 & $\mathrm{H}$ & & W & $\mathrm{R}$ \\
\hline & Bambusa vulgaris Schrad. ex J.C. Wendl. & Bans & 0.02 & $\mathrm{H}$ & & $\mathrm{Pl}$ & $\mathrm{M}, \mathrm{Ck}$ \\
\hline & Cynodon dactylon (L.) Pers. & Dubbaghass & 0.06 & $\mathrm{H}$ & $A^{*}$ & W & $\mathrm{M}, \mathrm{O}$ \\
\hline & Eleusine indica (L.) Gaertn. & Kodoghass & 0.01 & $\mathrm{H}$ & & W & $\mathrm{O}$ \\
\hline & $\begin{array}{l}\text { Thysanolaena latifolia } \\
\text { (Roxb. ex Hornem.) Honda }\end{array}$ & Berni & 0.01 & $\mathrm{H}$ & $\mathrm{Pl}^{*}$ & $\mathrm{PI} / \mathrm{W}$ & $\mathrm{O}$ \\
\hline & Triticum aestivum $\mathrm{L}$. & Ghehu & 0.01 & $\mathrm{H}$ & & $\mathrm{Pl}$ & $\mathrm{O}$ \\
\hline \multirow[t]{2}{*}{ Polygonaceae } & Polygonum dichotomum Blume. & Biskathali & 0.01 & S & & W & M \\
\hline & Polygonum hydropiper L. & Sukurpota, Biskutli, Pirrojhar & 0.02 & $\mathrm{H}$ & & W & $\mathrm{M}, \mathrm{O}$ \\
\hline Rubiaceae & Anthocephalus cadamba (Roxb.) Miq. & Kadam & 0.01 & $\mathrm{~T}$ & $S p^{*}$ & $\mathrm{PI} / \mathrm{W}$ & M \\
\hline \multirow[t]{3}{*}{ Rutaceae } & Aegle marmelos (L.) Corrêa & Bael & 0.06 & $\mathrm{~T}$ & $\mathrm{Pl}^{*}, \mathrm{R}^{* *}$ & $\mathrm{Pl}$ & $\mathrm{M}, \mathrm{O}, \mathrm{Ck}$ \\
\hline & Citrus limon (L.) Osbeck & Gololebu, Nimbu & 0.03 & $\mathrm{~S}$ & & $\mathrm{Pl}$ & $\mathrm{M}, \mathrm{O}, \mathrm{N}$ \\
\hline & Murraya koenigii (L.) Spreng. & Norsing, Karipatta & 0.01 & $\mathrm{~T}$ & & $\mathrm{Pl}$ & M \\
\hline Scrophulariaceae & Scoparia dulcis L. & Pith berela, Mithapatta,Chinipatta & 0.02 & $\mathrm{H}$ & $\mathrm{Co}^{*}$ & W & $\mathrm{M}, \mathrm{O}$ \\
\hline Simaroubaceae & Ailanthus integrifolia Lam. & Gokul & 0.02 & $\mathrm{~T}$ & $\mathrm{Sp}^{* *}$ & W/PI & O \\
\hline \multirow[t]{3}{*}{ Solanaceae } & Datura metel L. & Datura & 0.04 & $\mathrm{H}$ & & W & $M, O, B$ \\
\hline & Solanum indicum L. & Bithifal, Brihati, Rambegun & 0.01 & S & & W & M \\
\hline & Solanum khasianum C.B. Clarke & Bijri kata & 0.01 & $\mathrm{~S}$ & $S p^{* *}$ & W & O \\
\hline
\end{tabular}


Table 1 List of documented ethnobotanic plants used by the communities living in fringe villages of Chilapatta Reserve Forest (Continued)

\begin{tabular}{|c|c|c|c|c|c|c|c|}
\hline 1 & 2 & 3 & 4 & 5 & 6 & 7 & 8 \\
\hline & Solanum melongena $\mathrm{L}$. & Bagun & 0.01 & S & & $\mathrm{Pl}$ & M \\
\hline & Solanum nigrum L. & Maichung, Kakmachi & 0.01 & $\mathrm{H}$ & $A^{*}$ & W & M \\
\hline & $\begin{array}{l}\text { Solanum xanthocarpum Schrad. } \\
\text { \& J.C. Wendl. }\end{array}$ & Kantakari & 0.01 & $\mathrm{H}$ & & $\mathrm{PI} / \mathrm{W}$ & M \\
\hline Sterculiaceae & Sterculia villosa Roxb. & Udal & 0.01 & T & $S p^{* *}$ & W & N \\
\hline Thelypteridaceae & $\begin{array}{l}\text { Christella dentata (Forssk.) } \\
\text { Brownsey \& Jermy }\end{array}$ & Bis-dhekia & 0.01 & $\mathrm{~F}$ & & W & $\mathrm{O}$ \\
\hline Typhaceae & Typha elephantina Roxb. & Hogla, Bhoglapatta & 0.01 & $\mathrm{H}$ & & W & $\mathrm{O}$ \\
\hline \multirow[t]{3}{*}{ Verbenaceae } & Lantana camara L. & Ban-tulsi & 0.01 & S & $S p^{* *}$ & W & $\mathrm{O}$ \\
\hline & Tectona grandis L. f. & Segun & 0.01 & T & $\mathrm{Fr}^{* *}$ & $\mathrm{PI} / \mathrm{W}$ & $\mathrm{O}, \mathrm{M}, \mathrm{R}, \mathrm{Ck}$ \\
\hline & Vitex negundo L. & Nisinda & 0.01 & S & $\mathrm{Fr}^{*}$ & W & $\mathrm{O}$ \\
\hline \multirow[t]{2}{*}{ Vitaceae } & Cissus quadrangularis L. & Harjora & 0.02 & $\mathrm{H}$ & & W & $\mathrm{M}, \mathrm{O}$ \\
\hline & Cissus repanda Vahl & Panilarang, Panilata, Panilahara & 0.01 & C & & W & O \\
\hline Xanthorrhoeaceae & Aloe vera (L.) Burm. f. & Ghewkumari, Gritokumari & 0.03 & $\mathrm{H}$ & & $\mathrm{Pl}$ & $\mathrm{R}, \mathrm{O}, \mathrm{N}$ \\
\hline \multirow[t]{4}{*}{ Zingiberaceae } & Alpinia malaccensis (Burm.f.) Roscoe & Purundigach & 0.02 & S & & $\mathrm{PI} / \mathrm{W}$ & $\mathrm{R}, \mathrm{O}$ \\
\hline & Curcuma caesia Roxb. & Kala haldi, Kalohaledo & 0.03 & $\mathrm{H}$ & & W & $\mathrm{M}, \mathrm{R}, \mathrm{Ck}$ \\
\hline & Curcuma longa $\mathrm{L}$. & Halud, Haldi & 0.04 & $\mathrm{H}$ & $S p^{*}$ & $\mathrm{Pl}$ & $\mathrm{M}, \mathrm{O}$ \\
\hline & Zingiber zerumbet (L.) Roscoe ex Sm. & Jangliadha, Jangliadhua & 0.02 & $\mathrm{H}$ & & $\mathrm{PI} / \mathrm{W}$ & $\mathrm{M}, \mathrm{O}$ \\
\hline
\end{tabular}

1: family; 2: scientific name; 3: vernacular name; 4: use value; 5: plant form, 6: conservation status; 7: growing status; 8: community using the species

$M$ Mech, $R$ Rava, $O$ Oraon, $C k$ Chikbaraik, $C r$ Cherwa, $N$ Nepali, $B$ Bengali, Bi Bihari, $T$ tree, $H$ herb, $S$ shrub, $C$ climber, $C r$ creeper, $F$ fern, $F n$ fungus, $W$ wild, $S p$ sparse/less frequent, $P I$ planted, $A$ abundant, Fr frequent, Co common, $E$ endangered, $R$ rare

*[54] Chhetri et al. 2005

**[53] Shukla 2010

lucidum). Among these total species documented, 52 species were planted by the indigenous communities of forest fringe area, 62 species were growing wild or collected from the forest for use and 26 species were both wild and planted. Of these ethnomedicinally used species, trees dominated the list with 55 species (21 planted, 19 wild while 15 both growing wild and planted/domesticated) followed by herbs with 39 species (15 planted and 18 wild while 6 both growing wild and planted/domesticated), shrubs with 30 species (10 planted and 17 wild while 3 both growing wild and planted/domesticated), climber with 12 species (4 planted and 8 wild), ferns are Christella dentata and Diplazium esculentum (both wild) and least used was a creeper (Ipomoea batatas-planted) and a fungus (wild).

The tree species were represented by 44 genera and 29 families, shrubs represented by 26 genera and 17 families, herbs represented by 36 genera and 25 families, climbers represented by 10 genera and seven families, ferns represented by two genera and two families and one genus and one family each represented creeper and fungus. Trees were dominated by genus Ficus with six species and family Moraceae with nine species; shrubs were dominated by genus Solanum with three species and families Apocynaceae, Fabaceae, Euphorbiaceae and Solanaceae with three species each; herbs were dominated by genera Ageratum, Centella and Curcuma with two species each and family Poaceae with five species; and climbers were dominated by genera Coccinia and Dioscorea with two species each and family Cucurbitaceae with four species (Table 1).

The cultivated ethnomedicinal plant species were grown/planted by the respondents in their home garden, and it was found during the survey that almost all the respondents were maintaining a home garden contributing to conservation of the species they were using. Similar documentation was also reported by [10]. In total, 78 ethnomedicinal plant species were documented to be maintained in the home gardens by the indigenous community residing in and around the Chilapatta Reserve Forest of West Bengal. Similar report on home gardens maintaining rich biodiversity of ethnomedicinal plants was also reported from Ethiopia [18]. There are ample of similar documentation from the plains and Himalayan region of West Bengal including Sikkim Himalayas [18-27].

A similar study from the same study area a decade ago [10] reported 79 ethnomedicinal plant species represented by 41 families and 68 genera. This means an increment of use of 61 ethnomedicinal plant species by the community. A decade ago, the community were growing only 17 species in their home garden [10] but now, it increased to 78 species (present study). This increased the entries of 
ethnomedicinal plant species in the list which was documented a decade ago. This may be because of plant accessibility and visibility in the cultural landscape [28] increasing accessibility to obtain useful plants. The farther the species grows from home, the less frequently it is used, but if the plants are more desirable than well-known, species growing near home, it is worthwhile to domesticate these plants instead of undertaking long trips now and then. Plant accessibility and visibility in the cultural landscape [28] seem to have important factors influencing strategies for obtaining useful plants. Researchers conducting studies in different parts of the world indicate that knowledge of ethnomedicinal plants increases in proportion to their proximity to human habitations [29-31]. People usually know less about plants growing far from their homes and more about species that grow nearby. The same principle applies to use: people usually choose plants that grow in the immediate vicinity of their place of residence for ethnomedicinal use [32-34]. This explains the reason in increment in the number of planted ethnomedicinal plant species over a decade period in the study area.

\section{Ethnomedicinal uses}

The documented species were used to treat 58 human diseases or ailments. Eight diseases of animals were also reported to be treated by some of the documented species (Table 2) of humans and domestic animals, respectively. The ethnomedicinal information documented for these species was also validated with earlier studies (Tables 2 and 3). Thirty plant species which were not reported in previous studies from the area. Stomach-related problems were documented to be treated by the maximum number of plants (40 species) followed by cuts and wounds with 27 plant species and least with one species each for 17 diseases or ailments (Table 3). It was noted that the common day-to-day problems (fever, stomach-related disorders cuts, wounds and burns) were treated with many species. It was documented that the communities were treating severe diseases like cancer, pox, ulcer, tuberculosis, typhoid, malaria, pneumonia and bronchitis. An earlier study on Rava community using 41 ethnomedicinal species was also documented [35]. Nine plant species were also used as ethnoveterinary medicines to cure diseases/ ailments like tongue and mouth problem; cough, cold and worms; lactation problem; fatigue/weakness; diarrhoea; cuts and wounds; and appetiser (Tables 2 and 3). There are many ethnomedicinal studies that similarly documented the use of plant species used as ethnoveterinary medicines [1, 36-39].

Among the documented species, 92 species were used to cure multiple problems, while the rest were used to cure single disease each (Tables 2 and 3). Similar observation was also reported by [40]. The fungus Ganoderma lucidum is used for asthma and lung problem. It also lowers cholesterol. According to the respondents, Terminalia chebula is used to treat almost all diseases and mainly is used as an appetiser and to cure gastroenteritis, jaundice, liver, pneumonia, cough and cold. The maximum number of 12 diseases/ailments was cured by Melia azedarach followed by Centella asiatica and Rauvolfia serpentina which were used to cure 11 diseases/ailments each.

The majority of the plant species (108) had more than one part that was medicinally important (Table 2) as was also documented by [41]. The indigenous communities mainly used the leaf of the plant for their ethnomedicinal uses as this part was maximum used with 83 species followed by the fruit ( 55 species), and least was the seed with four species (Fig. 1a). The leaves of the ethnomedicinal plants were also documented to be used by the majority of remedies in traditional medicines in several reports $[20,41]$. The fruit was also reported as dominant and widely used part for traditional medicines $[11,26]$. The other parts used were branch (32 species), stem (28 species), bark (26 species), flower (23 species) and rhizome/ tuber (eight species). The whole plant of 24 species was used for ethnomedicinal purposes. Destructive harvesting is done when the whole plant is used. Even the sap, latex, resin and pulp of the plant species were also used. Harvesting patterns of the leaves or foliage, root, rhizomes and tubers indicate their possibility of vulnerability for becoming endangered as was earlier observed [10].

Proper selection of species, parts, as well as preparation and administration methods were very important in traditional healthcare systems. Ethnomedicinal formulations were administered both externally (skin, nasal, eye and dental) and internally as oral doses (Table 2) as was also observed by [10]. Most of the preparations were a mixture of different plant species, and in few cases, only one plant species was used. Different parts of a single species were also used to cure different diseases. Almost all plant parts were used to prepare different medicinal formulations: roots, rhizomes, tubers, bark, leaves, flowers, fruit, seeds, young shoots, whole plants, and gum and latex. Doses of these preparations were not standardised but administered on the basis of age, physical appearance and intensity of the illness. Children were usually administered with smaller doses than adult. The course of frequency of treatment is decided by the type of disease and its severity.

Mode of preparation included juice, paste, decoction, powder, infusion and chewing raw plant parts. The administration of the therapy is raw, dried form in small pieces or powdered, solution or mixed with water/milk/honey and paste/lotion. Generally, fresh part of the plant is used for the preparation of medicine [42]. The majority of formulations were prepared as juice followed by paste and decoction. Usually, the underground parts were used in dried 
Table 2 Ethnomedicinal uses of documented species and validated with earlier studies

\begin{tabular}{llll}
\hline Plants name/voucher no. & Uses (present study) & Therapy/procedure of use & Earlier studies \\
\hline Andrographis & Diabetes, liver problems, & Whole plant is crushed, mixed with water & Malaria, fever [25]; poison \\
paniculata & fever, cough and cold, & and consumed twice daily_early & bites, menstrual disorder [42]; \\
(Burm.f.) Wall. ex & stomach pain, malaria & morning in empty stomach and night & for skin boils leucoderma [62]
\end{tabular}

Nees

UBKV FOR 253

Justicia adhatoda

L. UBKV FOR 328
Cough and cold, paralysis, allergy, stop bleeding, cuts and wounds
Justicia

gendarussa

Burm. f.

UBKV FOR 329

Acorus calamus $\mathrm{L}$.

Joint pain

UBKV FOR 252
Cancer, septic, headache, cuts and wounds

Guts and wounds

Tongue problem of domestic animals

Jaundice, blood dysentery, diarrhoea post dinner for diabetes and liver

problem. Whole plant is soaked over night, and the solution is consumed empty stomach to get relief from fever, cough, cold, stomach pain and malaria. The solution is also a tonic drink for health.

5-6 leaves mixed with ginger is boiled half to its original amount and taken with honey for curing cough for 3 times a day. In serious case, it can be taken for 1015 days approximately. Leaf paste is rubbed on cuts and wound. Leaves are boiled and the solution is used for taking bath for curing itching and stopping bleeding. Leaf extract is added with mustard oil; Ocimum sanctum extract and ginger extract and heated lightly. One teaspoon and half cup of this mixture is administered orally in empty stomach to children and adult, respectively for treating cough and cold. Young leaves of Justicia adhatoda, papaya and Ocimum sanctum are packed under banana leaf and heated on a pan. After heating, its half teaspoon extract is administered empty stomach once a day as an alternate therapy for cough.

Leaf extract is heated with coconut oil and placed on the affected part of the body for curing cancer, sceptics and cuts. The extract is also applied on cut and wound for healing and on forehead for relief from headache.

Stem of Acorus calamus and leaves of Artemisia dubia are mixed and grinded to form a paste which is then applied on paining joints till it is cured.

Extract after crushing the twigs/leaves or flowers applied on cut or wounded part of the body and dressed.

Cloves are pasted and made solution with water and fed to suffering animals once for 2 days.

Tender leaves of Mangifera indica, Syzygium cuminii, and Psidium guajava are crushed sugar candy, mentha, Piper nigrum and Centella asiatica, and the extract is taken twice a day to cure diarrhoea. Bark is used for curing diarrhoea of domestic animals. Bark of Mangifera indica, ambera (sadri lang) and Syzygium cuminii are grinded and boiled with banana leaf and concentrated to one fourth of the initial volume. The concentrate is then administered orally to the patient to cure blood dysentery. One glass water solution of bark extract is
Cough, cold, piles, leprosy, diabetes, bronchitis, asthma, sinusitis, anti-inflammatory $[41,66,75,76,88]$

Rheumatism [83]

Delayed delivery, eye and skin problem [25]; throat infection [42]; asthma, bronchitis, dysentery [69]; rhizome to remove lice of animals [70] cough, whooping cough, bronchitis [64]

Indigestion, dysentery, cough and cold, worm, infection, hypertension, heat stroke, digestion $[10,25,26]$ 
Table 2 Ethnomedicinal uses of documented species and validated with earlier studies (Continued)

\begin{tabular}{|c|c|c|}
\hline Plants name/voucher no. & Uses (present study) & Therapy/procedure of use \\
\hline & & $\begin{array}{l}\text { consumed once a day in empty stomach } \\
\text { early in the morning for } 5-6 \text { days to cure } \\
\text { jaundice. }\end{array}$ \\
\hline
\end{tabular}

$\begin{array}{ll}\begin{array}{l}\text { Annona } \\ \text { squamosa L. } \\ \text { UBKV FOR 284. } \\ \text { Anethum graveolens }\end{array} & \text { Stomach disorders } \\ \text { L. UBKV FOR 283 } & \\ \text { Centella asiatica } & \text { Blood pressure } \\ \text { (L.) Urb. } & \text { Jaundice, typhoid, body } \\ \text { UBKV FOR 257 } & \text { pain, pneumonia, diabetes, } \\ & \begin{array}{l}\text { cough, gastroenteritis, } \\ \text { dysentery, stomach disorder, } \\ \text { appetiser, dog bite, vegetable }\end{array}\end{array}$

Centella annua M. Schub.

\& B.-E. van Wyk

UBKV FOR 301

Alstonia scholaris (L.) R. Br. UBKV FOR 09

Calotropis procera $\mathrm{R}$. Br. UBKV FOR 297

Gastroenteritis, stomach disorder, stomach pain, dysentery, liver problem,

Cough and cold, stomach worms of human and domestic animals, cough of domestic animals (pig), alcoholic beverage

Swelling body, hydrocoel and wounds, pneumonia,
Ripe fruit pulp are used for curing stomach problem.

Leaves are used in curry to control pressure.

- Leaves of Centella asiatica, bamboo and Ocimum sanctum with earthworm are boiled with water and sieved, and half a glass solution is taken for 3 times a day for 3 days to treat aundice and typhoid. - Leaves are eaten as vegetables which also help in removing body pain and fever.

- Leaf extract in water solution and one glass of this solution is taken during early morning in empty stomach to heal wounds.

- Roots are either eaten raw or cooked with potato (fried) for curing the pneumonia, jaundice and diabetes. - Besides this therapy, Centella asiatica, Piper nigrum and cardamom (2-3 nos.) are grinded and hot water solution is made which is orally administered for 34 days.

- Seeds of Piper nigrum, barks of Cinnamomom camphora, roots of halufan, and seeds of cardamom are mixed, grinded with Centella asiatica, made into tablets and sun dried which is consumed with hot water three times for phenomena, joint pain, appetite and cough.

- The plant/leaf extract is consumed empty stomach (2 spoons for $2-3$ days) to cure gasteroenteritis, dysentery and other stomach problems. It is also consumed as an appetiser and digestive tonic.

- The plant extract is mixed with sugar candy or palm candy taken 1 glass/day in empty stomach for 2-3 days to treat stomach disorders.

Paralysis, diabetes, fever, cuts

The plant is either cooked as vegetable or its extract is consumed to get relief from gasteroenteritis, dysentery and stomach disorders. Its extract solution with water is taken daily as liver tonic.

Smelling of flowers cure cough and cold.

Leaves are burnt lightly on fire and dressed on swelling area to get relief from pain. Leaves are smeared with vegetable oil and heated, then applied on scrotum to cure hydrosol. The process is continued for a week.

Roots are eaten in empty stomach or its powder/extracts can also be taken for at
Earlier studies

Diabetes and wounds $[25,63]$ ulcer, tumour [26]

Constipation, indigestion, diarrhoea, dysentery, stomach problems, stomach ache, skin disease, blood related problems, diabetes, tonsillitis, cold, health and memory tonics, insomnia, blood pressure, chicken pox, stomach worm, leucorrhoea, poor urination, jaundice $[10,11$, $22,25,35,41,42,49,55,63$, $72-74,77,81,82,87,88,91]$

Increase lactation [42];
Nocturnal eneuresis, tumour, leprosy, dropsy, cut and wound, $[25,66]$ 
Table 2 Ethnomedicinal uses of documented species and validated with earlier studies (Continued)

\begin{tabular}{lll}
\hline Plants name/voucher no. & Uses (present study) & Therapy/procedure of use \\
\hline UBKV FOR 271 & jaundice, stomach & least 3 months to cure diabetes. Leaves \\
worm, dysentery, snake bite, & are rubbed on the body for curing \\
gastroenteritis, stomach pain, & paralysis. Bark is grinded adding water \\
snake repellent & and kept for half an hour. This solution is \\
& taken as medicine for 3 times for curing \\
& fever and wounds. Leaf or root paste is \\
& applied on snale bite. It can simply be \\
& chewed to cure stomach pain, snake \\
bites and dysentery. Entire plant or any & other part is dried and powdered and \\
& taken in minute amount with water to \\
& cure jaundice. It should be taken in \\
empty stomach early in the morning for & $2-3$ days. Root extract solution (1-2 \\
drops for 2 days) is administered orally to & cure fever or stomach worms.
\end{tabular}

$\begin{array}{ll}\begin{array}{l}\text { Tabernaemontana } \\ \text { divaricata R. Br. ex Roem. }\end{array} & \text { Conjunctivitis } \\ \text { \&Schult } & \\ \text { UBKV FOR } 14 & \\ \begin{array}{l}\text { Thespesia populnea (L.) Sol. } \\ \text { ex Corrêa }\end{array} & \begin{array}{l}\text { Toothache, healing, cuts } \\ \text { andwound }\end{array} \\ \text { UBKV FOR } 354 & \\ \text { Colocasia esculenta (L.) } & \text { Malaria, blood purifier } \\ \text { Schott } & \end{array}$

UBKV FOR 22

Areca catechu L.

UBKV FOR 286

Cocos nucifera L.
UBKV FOR 309

Phoenix sylvestris (L.) Roxb. UBKV FOR 341

Hemidesmus indicus (L.)

Schultes

UBKV FOR 360

Asparagus racemosus Willd. UBKV FOR 255

Rob.

UBKV FOR 276
Earlier studies

Hypertension, insanity, blood

pressure, fever, malaria, snake

bite $[10,25,35,41,62]$

Flowers are simply rubbed on hands and its extract in the liquid form (only 1 drop for 2-3 days) is used to cure eye infection.

$-$

Periodic problems of women

Weight loss, hair vitalizer

Asthma, cough, dehydration, diarrhoea, fever, heart-related problems, pain, dental pain, tuberculosis

Skin infection

$$
-
$$

Massaging body, cuts and wounds
Fruits are cooked as vegetable and eaten with meal to cure malaria. This also cleanses blood.

Betel leaf and nuts are masticated to get relief from gastric problems. Young roots of Areca catechu and flowers of Hibiscus rosa sinensis are crushed together to extract juice. The juice is sieved, added with salt and lightly boiled which is then consumed twice daily by woman for 34 days.

Coconut milk is consumed to cure stomach problem, loose body fat and control hair loss.

Inflammation and wounds, nervous debility [86]

Root extract is added with water, sieved and solution is consumed in empty stomach daily for 4-5 days for curing urine disorder. Roots are also pasted with rice, mixed with half a glass of water and consumed in empty stomach for a week or two to get relief from body and kudney swelling. Leaf extract is applied on wounds of domestic animals and dressed.

Constipation, weakness, alopecia, blood circulation, cuts and injuries, liver problems, hair lengthening $[22,25,48,78,85]$

Itching, sore in nose [89]

Barks and roots are washed and cooked in oil then sieved to remove the solid particles. The oil solution used to massage any body part during winter once a day for 2 days. and jaundice, antifungal
Health tonic, brain tonic, cough and cold, cut and wound, fever, diabetes, dysentery, abortion, stomach disorder, piles, tuberculosis, bronchitis, back pain $[10,25$, $41,55,73,74,80,82-85]$

Cuts and wounds, dysentery $[11-13,55,71,73,74]$ 
Table 2 Ethnomedicinal uses of documented species and validated with earlier studies (Continued)

\begin{tabular}{|c|c|c|c|}
\hline Plants name/voucher no. & Uses (present study) & Therapy/procedure of use & Earlier studies \\
\hline & & $\begin{array}{l}\text { Leaves are crushed in between the palms } \\
\text { and then applied on cuts and bandaged. }\end{array}$ & \\
\hline $\begin{array}{l}\text { Ageratum conyzoides } \\
\text { L. UBKV FOR } 29\end{array}$ & Cuts and wounds & $\begin{array}{l}\text { Leaves are washed and crushed for } \\
\text { extracting its juice and applied on cuts } \\
\text { including leaves. It is tied with a piece of } \\
\text { cloth, which results in healing cuts as } \\
\text { well as stops bleeding. }\end{array}$ & $\begin{array}{l}\text { Stomach ache, cuts and } \\
\text { wounds, stop bleeding, } \\
\text { antihelmenthic } \\
{[64,72,75,78]}\end{array}$ \\
\hline $\begin{array}{l}\text { Eupatorium odoratum } \\
\text { L. UBKV FOR } 30\end{array}$ & Cuts and wound, bleeding & $\begin{array}{l}\text { Leaf extract is applied on cuts to stop } \\
\text { bleeding and healing as well. }\end{array}$ & Stop bleeding $[35,41]$ \\
\hline $\begin{array}{l}\text { Tagetes erecta L. } \\
\text { UBKV FOR } 352\end{array}$ & $\begin{array}{l}\text { Dental problem, mouth ulcer, } \\
\text { cuts and wounds }\end{array}$ & $\begin{array}{l}\text { Leaf extract is applied on cuts and } \\
\text { dressed for healing. Flower extract is } \\
\text { applied on mouth for healing ulcers. } \\
\text { Leaves are chewed early in the morning } \\
\text { to stop bleeding during brushing of } \\
\text { teeth. }\end{array}$ & $\begin{array}{l}\text { Blood coagulator, cuts and } \\
\text { wounds, }[41,67,82,87]\end{array}$ \\
\hline $\begin{array}{l}\text { Diplazium esculentum } \\
\text { (Retz.) Sw. } \\
\text { UBKV FOR } 33\end{array}$ & Stomach problem & $\begin{array}{l}\text { Leaves are cooked as vegetable and } \\
\text { eaten with rice for curing stomach } \\
\text { problem. }\end{array}$ & Constipation $[55,73,74]$ \\
\hline $\begin{array}{l}\text { Bombax ceiba L. } \\
\text { UBKV FOR } 35\end{array}$ & Stomach pain, diarrhoea & $\begin{array}{l}\text { Root extract administered orally twice a } \\
\text { day to treat diarrhoea. Tender leaves are } \\
\text { chewed raw in empty stomach twice a } \\
\text { day for } 2-3 \text { days to get relief from } \\
\text { stomach pain. }\end{array}$ & $\begin{array}{l}\text { Headache, fracture, blood } \\
\text { dysentery, pimples, skin } \\
\text { eruptions, tooth ache, leprosy, } \\
\text { gonorrhoea, diabetes, pimples, } \\
\text { anaemia, and scorpion sting, } \\
\text { virility }[10,25,35,41,55,63,64 \text {, } \\
72-74,81,88]\end{array}$ \\
\hline
\end{tabular}

Basella alba L.

Oroxylum indicum (L.)

Benth.

UBKV FOR 34 UBKV FOR 292

Skin burns, blood pressure

Jaundice, cuts and wounds, body pain, liver problem

kin eruptions, ulcers, headache

Bailey

UBKV FOR 294

Ananas comosus (L.) Merr. UBKV FOR 282

Opuntia ficus-indica Haw. UBKV FOR 340

Carica papaya $\mathrm{L}$. UBKV FOR 298

Chenopodium album L. UBKV FOR 302

Tuberculosis

Gastroenteritis, appetiser, digestive
The entire plant is pasted and applied on infected part once to get relief from burn. Cooked as vegetable to reduce blood pressure but is not taken by people having cut and wounds.

Flowers and leaves are cooked and taken with meal for curing jaundice and regulate blood pressure. Bark soaked in water used for taking bath also cures jaundice. Bark powered and mixed in water for taking bath is used for curing pneumonia. Dried bark powder is applied on cuts and wounds to heal. Bark extract consumed early in the morning for 56 days cure jaundice and liver problem. $-$

Two teaspoons of leaf extract are consumed in empty stomach daily for 23 weeks against stomach worms.

Jelly-type branch after peeling is cooked with wild onion and ghee till it is completely dried which is then consumed after meal three times a day to cure tuberculosis.

Unripe fruits cooked and eaten to improve digestion or eaten raw to get relief from oral infection. Flowers are cooked as vegetable to maintain appetite. Both ripe or unripe fruits are eaten to cure gasteroenteritis.

Plant is cooked as vegetable and consumed for clearing stool, curing piles and gasteroenteritis.
Tuberculosis, dysentery, constipation, intestinal disorder, vomiting $[41,55,73$, $74,81]$

Jaundice, regulate blood pressure, cough, fever, pneumonia, stomach/chest/ body pain, bronchial asthma, diarrhoea, dysentery, joint pain, appetiser, [10-12, 35, 41, 64]

Leaf extract to kill worms; fruit juice against scurvy [41]

Digestion, jaundice, dysentery, tooth ache, cough, indigestion, liver tonic, piles, heart problem, skin infection, fracture $[11,25$, $55,73,74,76,78,81,82]$

Fever and influenza, constipation, intestinal worms $[75,76,81]$ 
Table 2 Ethnomedicinal uses of documented species and validated with earlier studies (Continued)

\begin{tabular}{llll}
\hline Plants name/voucher no. & Uses (present study) & Therapy/procedure of use & Earlier studies \\
\hline Terminalia arjuna (Roxb.ex & Asthma, heart problem, & Bark extract solution is administered & Skin disease, leucoderma, liver \\
DC.) Wight \& Arn. & diabetes, stomach disorder, & orally to cure heart problem. Bark of & disorder, fractured bones, \\
UBKV FOR 272 & gastroenteritis, appetiser & Terminalia arjuna, Alstonia scholaris and & tuberculosis, cardiac problem, \\
& & fruits of Terminalia chebula, Terminalia & hypertension, pimples and \\
& bellirica and Emblica officinalis are & other minor skin eruption, \\
& powdered and its solution in a glass of & cardio tonic $[25,41,63,86,88]$
\end{tabular}

Terminalia bellerica

(Gaertn.) Roxb.

UBKV FOR 45
Cough and cold, stomach disorder, indigestion, gastroenteritis
Terminalia chebula Retz. UBKV FOR 46 the morning for 5-6 days as appetiser and cure gastroenteritis. Small pieces of bark is boiled in water and concentrated, cooled and taken in doses of two teaspoon of this cooled solution is consumed twice a day before meal or the bark pieces are powdered adding sweet candy and two teaspoon of this powder is consumed mixed in a glass of water to cure diabetes. Bark is soaked in water overnight and the solution is taken early in the morning for curing gastroenteritis and also as liver tonic. Half glass bark extract in water solution is administered orally twice a day for 57 days for curing breathing and heart problem.

Terminalia bellirica, Piper nigrum, Terminalia chebula, cloves and Cinnamomom camphora are crushed together and made into tablets which are administered in empty stomach for curing cough. A glass of root extract is administered once a day for a week in empty stomach to cure stomach disorder. Besides the root xtract is also used to massage on stomach where pain is felt. Fruits are crushed into tablets and administered in empty stomach once a day to cure cough and cold. Fruit pulp extract is boiled (1 $\mathrm{kg}$ fruit in $2 \mathrm{l}$ ) and the hot solution is consumed for curing gasteroenteritis. Fruit pulp is crushed to tablets and taken empty stomach twice a day for a month for curing severe cough and cold. Dry fruit is crushed to powder and swallowed to cure stomach problem.

Fruits of Terminalia chebula, Terminalia bellirica, and Emblica officinalis are dried and one fruit of each is soaked in water for $24 \mathrm{~h}$ and taken in empty stomach for making the liver strong and also as appetiser. Parts of plants are beaten to powder or is boiled and consumed twice a day for curing any kind of sickness. Fruits are crushed and mixed with water consumed for treatment of cold and cough. Two teaspoons dried fruit pulp powder is consumed twice a day in empty stomach for indigestion, cough and cold. Fruit pulp is boiled, cooled and the solution is consumed emptyty stomach (one glass a day for 4-5 days) for curing cough. Flowers are cooked and consumed to cure cough. Fruit pulp is boiled with black salt, crushed into tablets, sundried for few days and then consumed early in the morning to cure gastroenteritis. Fruits are soaked over night in water overnight and then the
Skin disease, cold, constipation, leucoderma, grey hair, rheumatism, diarrhoea, dysentery, indigestion, dyspepsia, cooling agent, health tonic, cuts and wounds, tonsillitis, bronchitis, piles, dropsy, leprosy, headache, asthma $[10,11,41$, $48,55,62,63,73,74,78,86]$

Carminative, laxative, digestive, appetiser, constipation, piles, stomach disorder/pain, tonsillitis, diabetes, intestinal ulcer, rheumatism, urinary problem, skin problem, cold and cough, respiratory troubles, fever $[10,11,25,41$, $42,55,62,63,73,74,78,80,86]$ 
Table 2 Ethnomedicinal uses of documented species and validated with earlier studies (Continued)

\begin{tabular}{|c|c|c|c|}
\hline Plants name/voucher no. & Uses (present study) & Therapy/procedure of use & Earlier studies \\
\hline & & $\begin{array}{l}\text { solution is taken in empty stomach as } \\
\text { appetiser, cure jaundice and making liver } \\
\text { strong. Fruits are also chewed to get } \\
\text { relief from cough and cold as well as } \\
\text { pneumonia. }\end{array}$ & \\
\hline $\begin{array}{l}\text { Cuscuta europaea } \\
\text { L. UBKV FOR } 311\end{array}$ & Jaundice & $\begin{array}{l}\text { The whole plant is boiled and either } \\
\text { taken bath with light warm water once a } \\
\text { day for } 2-3 \text { times or a glass of this } \\
\text { solution mixed with salt is consumed as } \\
\text { a therapy for jaundice. }\end{array}$ & - \\
\hline
\end{tabular}

Ipomoea batatas (L.) Lam. UBKV FOR 326

\section{Ipomoea carnea Jacq. UBKV FOR 327}

Bryophyllum pinnatum Kurz. UBKV FOR 295

Coccinia coridifolia Cogn. UBKV FOR 307

Coccinia indica $\mathrm{L}$. UBKV FOR 308

Lagenaria siceraria (Molina)

Standl.

UBKV FOR 330

Luffa aegyptiaca Mill.

UBKV FOR 332

Momordica dioica Roxb. ex Willd.

UBKV FOR 335

Dillenia indica $\mathrm{L}$. UBKV FOR 62

Dioscorea belophylla Voigt UBKV FOR 65

Dioscorea bulbifera

L. UBKV FOR 312

Shorea robusta Gaerth $\mathrm{f}$. UBKV FOR 68

Elaeocarpus ganitrus Roxb. ex G. Don UBKV FOR 313

Baccaurea remiflora Lour. UBKV FOR 289
Tumours of the mouth and throat, asthma, burns, fever, diabetes

Fungal infection between toes and fingers

Burn injuries, cuts and wound

Lowers blood pressure

Lowers blood pressure, gastroenteritis

Boils

Anaemia, liver disorder, menstrual problems

Stomach disorder, fever

Stomach disorder

Appetiser, jaundice, body pain, stomach disorder, pneumonia

Jaundice

Cuts and wounds, burns, stomach pain, blood coagulant, dysentery

Piles, good sleep, asthma, cough

Skin disease
Rhizomes are cooked and consumed by diabetic patients

Leaves are grinded, applied on affected part and dressed.

Fruits are cooked as vegetables and taken with meal to lower blood pressure.

Fruits are chewed or cooked as vegetables to lower blood pressure. Leaves are pasted and added with water. It is consumed for curing gasteroenteritis. Tender leaf extract are used to treat boils.

Fruits are consumed to cure stomach disorder. One glass leaf extract twice a day is consumed for 2 days to cure fever.

Bark is boiled and taken for curing stomach disorder.

Fruits are cut into pieces and soaked in water overnight, boiled and eaten as appetiser. Tuber is crushed and messaged on the whole body once a day to get relief from pain. Tuber is cut into pieces and partially boiled and is dip in water for a night. In morning it is fried as curry with little oil and eaten with meal for 3-4 days for curing pneumonia.

Tubers are crushed and soaked in water for 5-10 min. One glass of this solution is consumed to treat jaundice.

Bark powder/extract is and mixed with water to form solution and taken 3 times a day in empty stomach for curing stomach problems. Bark powder is applied on burns once a day for 3-4 days for relief.
Diabetes, scorpion sting $[12,72,76]$

Fungal infection between toes [76]

Gall bladder stone, piles, stomach problems, antiseptic, kidney stone, skin disease $[25,88]$

$-$

Hypertension, healing wound, ulcer, jaundice [26]

Jaundice, diarrhoea and dysentery $[72,75]$

$-$

Urinary trouble, piles, diabetes, jaundice, ulcer, dysentery, ear pain, breast swelling, hair vitalizer [55, 72-74, 83, 85]

Bark to get relief from indigestion, gasteroenteritis, diarrhoea $[10,55,65,73,74]$

Gonorrhoea, diarrhoea, dysentery, burning sensation, chest pain, pox, ear pain $[25,41,55,73,74$, $78,82]$ 
Table 2 Ethnomedicinal uses of documented species and validated with earlier studies (Continued)

\begin{tabular}{llll}
\hline Plants name/voucher no. & Uses (present study) & Therapy/procedure of use & Earlier studies \\
\hline Baccaurea sapinda & Tooth ache & $\begin{array}{l}\text { Twigs are used to brush teeth to get } \\
\text { relieve from tooth pain. }\end{array}$ & - \\
(Roxb.) Müll.-Arg & &
\end{tabular}

UBKV FOR 290

Codiaeum variegatum (L.)

A. Juss.

UBKV FOR 310

Gastroenteritis, ulcers, fencing, decorative, religious, fuel wood

Emblica officinalis Gaerth. UBKV FOR 263
Hair loss, liver problem, stomach pain
Hevea brasiliensis (Willd. ex A. Juss.) Müll.-Arg. UBKV FOR 323

Jatropha curcas L. UBKV FOR 264

Mallotus tetracoccus (Roxb.)

Kurz.

UBKV FOR 333

Ricinus communis

L. UBKV FOR 84

Acacia catechu (L. f.) Willd. UBKV FOR 251

Acacia nilotica (L.) Delile UBKV FOR 275
Ornamental (landscape)

Diarrhoea, headache

Skin diseases, ring worm

Cough, headache, dental problem, jaundice

Cuts and wounds, burns, sore throat, diarrhoea, digestion

Evil spirit

Stomach pain

Bauhinia malabarica Roxb. UBKV FOR 293

Cajanus cajan (L.) Mill UBKV FOR 296
Gall bladder stone, diabetes, jaundice and liver problem
The whole plant is simply used for fencing purpose, decorative purpose, after the plant is dried it is used as fuel wood, and the leaves is used as religious purpose (puja).

Raw fruits are eaten to get relief from stomach pain. Fruits of Emblica officinalis, Terminalia chebula and Terminalia bellirica are dried, crushed and made into powder. One teaspoon of this powdered in water solution is consumed daily early in the morning to restrict hair loss and to cure liver problem.

$-$

Sugar candy and few drops of Jatropha curcas latex are mixed and consumed for treatment of diarrhoea. Seeds are pasted with water and applied on forehead for curing headache.

$-$

Leaf extract is massaged in neck for 3 times a day for 5 days for curing cough; however during the therapy period nonvegeterian food is avoided. Seed oil ex tract is applied on head to get relief from headache. Leaf extract is mixed with sugar and consumed for 3-4 days to cure jaundice. Alternately, fruits are also boiled with grains of Cajanus cajan and con sumed to cure jaundice. Twigs are used for brushing teeth for healthy dentals.

Soft wood is cut in small pieces and boiled with water for some time and left for cooling to soilidify. The preparation is smeared with betel leaf for chewing to cure gastric problem.

Dental problems

Leaves are boiled and consumed daily for 2-3 months to get relief from stomach pain after pregnancy.

Leaf extract is taken to cure diabetes. Fruits are eaten to get rid of gall bladder stone. Leaf extract solution is made with $200 \mathrm{ml}$ of water and $100 \mathrm{~g}$ of either palm
Constipation, fever, itching, digestive, gasteroenteritis, haemorrhage, jaundice $[25,64]$

Cuts and wounds, skin disease, seeds digestive, twigs used in tooth and gum problem, rheumatic pain, night blindness $[10,25,35,61,75]$

Piles, wounds (human and animal), joint pain, jaundice, headache, fever, boils, dysentery, stomach problems, indigestion, skin disease, hair loss, sores, boils, burns, rheumatic swelling, stomach worms $[10,11$, $25,55,67,68,73,74]$

Leaf for indigestion, bark, gum and root to control rheumatism [10]; body ache, fracture [55]; toothache, cough and cold, stomach pain [25]; astringent, boils and skin eruptions, diarrhoea and dysentery, bleeding from nose, chest pain [64-67]

Jaundice, itching, skin disease, worms, maggot wounds, dental problems, easy delivery, burns, asthma, fever, headache, stomach problems, indigestion, cholera, diarrhoea, dysentery $[25,63,66,67]$; indigestion and gas problem of cattle [68] $-$

Jaundice, dysentery, ear pain $[41,83,89]$ 
Table 2 Ethnomedicinal uses of documented species and validated with earlier studies (Continued)

\begin{tabular}{|c|c|c|}
\hline Plants name/voucher no. & Uses (present study) & Therapy/procedure of use \\
\hline & & $\begin{array}{l}\text { candy or sugar candy and administe } \\
\text { orally once in the morning for } 3 \text { day } \\
\text { empty stomach. Roots are also used } \\
\text { curing jaundice by grinding them w } \\
\text { water, sieved and } 200 \mathrm{ml} \text { solution } \\
\text { administered orally early morning in } \\
\text { empty stomach for } 3 \text { days. }\end{array}$ \\
\hline $\begin{array}{l}\text { Cassia alata L. } \\
\text { UBKV FOR } 299\end{array}$ & $\begin{array}{l}\text { Bees sting, allergy, appetiser } \\
\text { for children, weakness }\end{array}$ & $\begin{array}{l}\text { Leaves are crushed and applied on } \\
\text { sting and infected area of skin infect } \\
\text { Bark extract is consumed for appetis } \\
\text { and health tonic. }\end{array}$ \\
\hline $\begin{array}{l}\text { Cassia sophera L. } \\
\text { UBKV FOR } 300\end{array}$ & $\begin{array}{l}\text { Dysentery, cuts and wounds, } \\
\text { cough, blood purifier }\end{array}$ & $\begin{array}{l}\text { Leaf, flower and root extract is consu } \\
\text { to cure dysentery, wounds, cough al } \\
\text { purify blood. }\end{array}$ \\
\hline $\begin{array}{l}\text { Hippocrepis emerus (L.) } \\
\text { Lassen } \\
\text { UBKV FOR } 325\end{array}$ & Skin infection & $\begin{array}{l}\text { Leaves are crushed and rubbed on } \\
\text { infected skin for curing. }\end{array}$ \\
\hline $\begin{array}{l}\text { Mimosa pudica L. } \\
\text { UBKV FOR } 93\end{array}$ & Reddening of eye & $\begin{array}{l}\text { Leaf extract not more than a drop is } \\
\text { applied for curing red eye. }\end{array}$ \\
\hline
\end{tabular}

Pongamia pinnata $\mathrm{L}$ Swelling, tooth pain UBKV FOR 344

Tamarindus indica $\mathrm{L}$. UBKV FOR 353

Trigonella

foenum-graecum $\mathrm{L}$. UBKV FOR 356

Quercus castanopsis H. Lév. UBKV FOR 346

Ganoderma lucidum (Curtis)

P. Karst.

UBKV FOR 322

Clerodendrum viscosum

Vent.

UBKV FOR 246

Diabetes, joint pain
Gmelina arborea Roxb. UBKV FOR 247

Leucas aspera (Willd.)

Spreng.

UBKV FOR 331
Neck pain

Asthma, lungs problem, lowers cholesterol

Skin disease, stomach worm, stomach pain, tooth pain
Seed oil extract is massaged to reduce swelling. Tender branches are used as tooth brush to cure dental pain.

Fruits are soaked in cold water for $2-$ 3 days, mixed intensively and seeds are removed. The solution is taken a glass a day for curing neck pain, tonsil and swelling. Leaves can also be eaten for curing neck pain and swelling for both human beings and animals.

Whole plant is cooked and consumed to cure diabetes and joint pain. Seeds are also taken in empty stomach with water to curb diabetes.

Flowers are eaten for removing fish or meat bones stuck in the neck.

The fruiting body is cooked as vegetable and consumed to control the diseases/ ailments.

Leaves are boiled taken bath to get cure from body itching. Tender leaves and Centella asiatica are crushed, and the extract (1-2 teaspoons for children and adult, respectively) is consumed in empty stomach twice a day for 3 days to get relief from stomach worm and stomach pain. Twigs are used to brush the teeth to get relief from tooth ache.

Appetiser, piles, abdominal pain, Flowers are cooked and consumed to burning sensation, fever, headache, ulcer

Stomach disorder, swelling, headache, stop bleeding, headache, body pain, tooth pain, cuts and wounds control the diseases/ailments.

Half a cup leaf extract with salt is takenr 2-3 times a day to cure stomach disorder or swelling. Leaf extract or any plant part is inhaled to get relief from headache. Leaf extract is applied on cuts to stop bleeding and heal as well. Tender plant is
Earlier studies

Skin disease, body pain $[35,41]$

Diabetes [40]

$-$

Orchitis and depurative, infertility, dental pain, head ache, kidney/ urine trouble, piles, sores, diarrhoea, dysentery, hydrocoel, jaundice, wounds and swelling, placenta prolepses $[10,25,55,61$, $64,71,73,74,76]$

Fever [67]

Diarrhoea/dysentery (human and animals), indigestion, fever, piles, ulcer, nausea, vomiting, swelling, jaundice, gastropathy, wounds, scorpion bite, scabies, stomach pain, boils, cold, cough, skeletal flurosis [11, 26, 27, 67]

Alopecia, diabetes, stomach problems, easier pregnancy, diarrhoea of animals, increase lactation of cattles, joint pain of animals, $[22,61,68]$

$-$

Pain, skin disease [41]

Vomiting, diarrhoea, weakness, snake bite, cut and wound, piles $[25,41,42]$

Cuts and worms of cattle [37]; skin disease, sore in thigh [90] 
Table 2 Ethnomedicinal uses of documented species and validated with earlier studies (Continued)

\begin{tabular}{|c|c|c|}
\hline Plants name/voucher no. & Uses (present study) & Therapy/procedure of use \\
\hline & & $\begin{array}{l}\text { cooked and consumed to get relief from } \\
\text { body pain and gastroenteritis. Leaves are } \\
\text { dried, mixed with raw rice and } \\
\text { powdered, and half cup of its water } \\
\text { solution is consumed in empty stomach } \\
\text { daily for } 2-3 \text { days to remove swelling. } \\
\text { Roots are chewed after dinner for } 3- \\
4 \text { days to get relief from dental pain. }\end{array}$ \\
\hline $\begin{array}{l}\text { Ocimum sanctum L. } \\
\text { UBKV FOR } 267\end{array}$ & $\begin{array}{l}\text { Cough and cold, neck pain, } \\
\text { cancer, gastroenteritis }\end{array}$ & $\begin{array}{l}\text { Leaf extract of Ocimum sanctum and } \\
\text { Justicia adhatoda are mixed with water, } \\
\text { sieved and the solution is mixed with } \\
5 \mathrm{ml} \text { honey which is consumed } 3-4 \\
\text { times a day for } 2 \text { days to cure cough. } \\
\text { Leaves mixed with ginger are chewed to } \\
\text { get relief from cough and cold. Taking } \\
\text { three leaves daily anytime with water in a } \\
\text { day helps to keep cancer away. For } \\
\text { curing gastroenteritis and cough, leaf } \\
\text { extract can be taken any time in a day. } \\
\text { Dried young stem are laced and tied } \\
\text { around neck to avoid any disease. }\end{array}$ \\
\hline
\end{tabular}

Cinnamomom camphora

(L.) J. Presl

UBKV FOR 303

Machilus villosa (Roxb.)

Hook. f.

UBKV FOR 361

Careya arborea Roxb.

UBKV FOR 125

Lagerstroemia speciosa (L.)

Pers.

UBKV FOR 138

Punica granatum L. UBKV FOR 345

Abroma augusta (L.) L.f. UBKV FOR 274 to increase blood. hour to get relief from pain.
Stomach disorder, diabetes, reduce weight

Joint pain

Body pain, dysentery

Ulcers and sore, diabetes, piles, to obtain white and strong teeth,

Nose bleeding

Leaves of Punica granatum and black cumin are grinded adding water and 2-3 drops are dropped in nose to stop nose bleeding. Fruits when ripe are consumed

Night wetting, jaundice and stomach disorders

Tonsillitis, dandruff, hair loss

Dried bark or leaves can be taken as such for curing stomach disorder, diabetes and also helps in reducing weight.

Bark extract is placed on joints for an

Bark extract is sieved and solution is taken in empty stomach once a day for 3-4 days to cure dysentery. Bark extract is also administered externally to get relief from body pain.

For night wetting — bark of A. augusta and early roots of Bombax ceiba are mixed, washed and grinded into paste with palm candy. The paste is mixed with required amount of water and sieved. The solution is taken in empty stomach twice a day till the problem persists. paste is made after grinding with sugar candy. The paste is mixed with water and stored overnight. The solution is taken in empty stomach during early hours of morning for 3 days.

For stomach disorder-roots and barks are washed, grinded lightly and soaked in water for overnight to form a jelly-like so lution. The jelly is taken in empty stom ach once a day for 5 days.
Earlier studies

Asthma, cold and cough, fever, bronchitis, genito-urinary disorders, diaphoteric, antiperiodic, stimulating For jaundice-bark of roots is peeled and
$[10,11,41,64,69,82]$

Dysentery, cough, mouth and throat infection $[41,84]$

Diarrhoea, dysentery, bronchitis, fever, indigestion, heart problem, eye and ear infection, jaundice, nasal congestion $[25,55,64,66$, 73, 74]

Menstrual disorder, snake bite [55]; blood dysentery, diarrhoea, night wetting, [61]

Mennorrhagia dysentery, fever, headache, burn, boil, skin disease cough and cold, fatigue, hair fall, abortion, burning sensation, twitching $[25,41,62,72,82]$ 
Table 2 Ethnomedicinal uses of documented species and validated with earlier studies (Continued)

\begin{tabular}{llll}
\hline Plants name/voucher no. & Uses (present study) & Therapy/procedure of use & Earlier studies \\
\hline Melastoma & $\begin{array}{l}\text { Cuts and wounds, stomach } \\
\text { malabathricum L. }\end{array}$ & - & Pneumonia, diarrhoea [55, 73, 74] \\
UBKV FOR 144 & $\begin{array}{l}\text { dental pain } \\
\text { U }\end{array}$ & &
\end{tabular}

Azadirachta indica A. Juss. UBKV FOR 256

Melia azedarach L. UBKV FOR 334

Tinospora cordifolia (Willd.) Miers ex Hook. f. \& Thom. UBKV FOR 146

Entada rheedii Spreng.

\section{Artocarpus hetrophyllus \\ Lam}

UBKV FOR 254

Artocarpus lakoocha Roxb. UBKV FOR 154

Ficus benghalensis $\mathrm{L}$. UBKV FOR 316 UBKV FOR 315

Allergy, fever, pneumonia, small pox, appetite problem, brushing teeth, stomach tooth pain

Fatigueness, cough, fever, appetiser, deworming, cuts and wound, vomiting, skin disease, dental problem, piles, pox, mosquito repellent, purify blood,

Stomach pain, diabetes

Diarrhoea of domestic animals

Skin diseases, asthma, ulcers

Skin ailments, headache

Chronic diarrhoea and dysentery, piles

Swellings, tumours, ulcers

Fever

Ficus elmeri Merr. UBKV FOR 318

Ficus geniculata Kurz UBKV FOR 319

Ficus hispida L. f. UBKV FOR 320

Diarrhoea

Ulcer, jaundice, fever, liver problems disorder, skin disease,

Leaf extract in water solution taken twice a day in empty stomach to get relief from fever. way for fever. Half a glass juice extract is also administered orally daily for 3-4 days to cure pneumonia. Leaf extract is also consumed as appetiser. Leaves are boiled in water and used for taking bath for curing itching, fever and pox. For curing fever, leaves of neem and rice are grinded to powder and taken 1 spoon twice a day in empty stomach. Leaves are fried and consumed to cure mouth ulcers. Twigs are used to brush the teeth to get relief from tooth pain and dental problems. Leaves are beaten into tablets, sun dried and taken in empty stomach for curing gastric, appetite problems, fever, and other stomach disorder. $-$

Small pieces of roots are soaked in water overnight and the solution is consumed empty stomach early in the morning 1-2 times a day for 3-6 months to cure diabetes and stomach pain.

The fruit pulp is crushed mixing with water and salt to feed domestic animals on banana leaf for treating diarrhoea.

Mature leaves are chewed mixed with salt.

Paste of leaf and bark are applied on infected part

Latex in water solution is used orally for treatment of piles. Bark extract for diarrhoea/dysentery.

$-$

Leaves are boiled, and luke warm solution is taken for 1-2 days or leaf can be chewed for curing fever.

Tender leaves either after cooking consumed or dried, powdered and consumed in water solution to cure diarrhoea.
Domestic animals is also treated same

Allergy, skin disease, fever, boils, cut and wounds, cough and cold, eye and ear infection, dental problems/tooth brush, leprosy, intestinal worms, ulcer, stomach, ear and tooth ache, acidity, vomiting, blood sugar, diabetes, malaria, blood purifier, heart problems, typhoid, health tonic, cancer $[10,22,25,27,41,55,63$, $72-75,80-82,86,87]$

Blood purifier, reduce blood pressure, skin disease, head ache, fever, stomatitis, stomach worm, stone in urinary bladder, fever, antiseptic [12, 25, 68, 74, 79, 68]

Rheumatism, jaundice, diabetes, burning sensation during urination, piles, eye infection, fever, diarrhoea, dysentery, malaria, skin disease, appetiser $[10,25,55,62,72-74,80]$

Cuts and wounds, skin disease $[55,73,74]$

Antiseptic [26]; fever, boil, cut and wound, skin diseases, diarrhoea, toothache, snake bite $[35,55,61,64,73,74]$

Leaf and bark to treat skin disease [10]

Diabetes, gout, dysentery, diarrhoea, asthma, muscular pain, gasteroenteritis, hair vitaliser, joint pain, sexual disorder, stomach pain, dental problem $[12,25,26,55,63,71$, $73,74,86]$

Constipation [20]

Control blood sugar level, mouth ulcer $[35,41]$ 
Table 2 Ethnomedicinal uses of documented species and validated with earlier studies (Continued)

\begin{tabular}{|c|c|c|}
\hline Plants name/voucher no. & Uses (present study) & Therapy/procedure of use \\
\hline $\begin{array}{l}\text { Ficus racemosa } \mathrm{L} \text {. } \\
\text { UBKV FOR } 321\end{array}$ & $\begin{array}{l}\text { Mouth disease of } \\
\text { domestic animals }\end{array}$ & $\begin{array}{l}\text { Leaves are fed to the cattle/goat to cure } \\
\text { their mouth disease. }\end{array}$ \\
\hline $\begin{array}{l}\text { Morus alba L. } \\
\text { UBKV FOR } 337\end{array}$ & $\begin{array}{l}\text { Jaundice, fever, appetiser } \\
\text { for domestic animal }\end{array}$ & $\begin{array}{l}\text { Roots are cut into small pieces, wrapped } \\
\text { in cloth and tied on neck for } 12 \text { days or } \\
\text { leaves are boiled and after cooling the } \\
\text { solution is consumed once a day to cure } \\
\text { jaundice. }\end{array}$ \\
\hline $\begin{array}{l}\text { Moringa oleifera L. } \\
\text { UBKV FOR } 336\end{array}$ & $\begin{array}{l}\text { Blood pressure, gastroenteritis, } \\
\text { cold and cough, body pain, } \\
\text { clearing stool, cuts } \\
\text { and wounds of domestic } \\
\text { animals, snake repellent }\end{array}$ & $\begin{array}{l}\text { Leaf extract is taken to cure high pressure } \\
\text { and gastroenteritis ( } 1 \text { glass for } 2- \\
3 \text { months daily). Root extract are helpful } \\
\text { to cure cold and cough and heal wounds } \\
\text { of domestic animals. Pods are eaten as } \\
\text { vegetable which also help to regulate } \\
\text { blood pressure and body pain. Tender } \\
\text { leaves are also cooked as vegetables to } \\
\text { cure gastric, body pain, digestion and } \\
\text { clearing stool. Roots are cut into small } \\
\text { pieces and spread around the house as } \\
\text { snake repellent. }\end{array}$ \\
\hline
\end{tabular}

Earlier studies

Leucorrhoea, piles, stomach pain, dysentery, fiver, ulcer [25]

Sore throat, cough, brain and heart tonic $[55,73,74]$

Tumours, leucoderma, liver disorder, snake bite, piles, cough, stomach worm, diarrhoea, dysentery $[25,55,73,74,81]$
Musa balbisiana Colla UBKV FOR 338
Liver problem, gastroenteritis, dysentery, swelling, body severing, stomach disorder, teeth pain
Myristica longifolia Wall. UBKV FOR 165
Stop bleeding, cough

Dysentery/loose motion, stomach pain

\section{Dark black roots of banana and \\ Clerodendrum viscosum are crushed to paste and placed on chicks facing sunlight for an hour to get relief from dental pain. A full teaspoon of latex is consumed three times a day for 3 days to cure loose motion. Fruits or flowers are cooked and taken with daily meal to curing stomach disorder. Roots of banana are used for a night to reduce swelling and control body shiveringt. Ripe fruits or a cup of pseudostem sap is orally taken once for curing dysentery. One cup tender leaf extract solution is taken empty stomach early in the morning for at least 15 days to cure liver problems and dysentery. Fruit peel is pasted, mixed with glass of water and is consumed once in a day in empty stomach for about 15 days for curing gastroenteritis.}

Roots are soaked for few minutes and boiled in water till it turns red in colour. One cup of this solution after cooling is consumed as health tonic in empty stomach once a day for 3 days. The solution is also fed to domestic animals. Roots are crushed; boiled with water, cooled and one cup of this solution is taken daily twice for 3 days to stop menstrual bleeding. Root extract water solution of young plants is taken to cure cough.

Psidium guajava $\mathrm{L}$. UBKV FOR 270
Ripe fruits or tender leaves are eaten for curing dysentery. Tender leaves are chewed in empty stomach for 3-4 days or can be crushed and taken with adding water for curing stomach pain. Tender leaves extract ( $2-3$ spoons) is taken for 2-3 times a day till loose motion is cured.
Cold and cough, fever (human and animal), indigestion, dysentery, diarrhoea (human and animal), ulcer, vomiting, dental pain, joint pain, dental pain $[10,11,25,41,55,64,73,74]$ 
Table 2 Ethnomedicinal uses of documented species and validated with earlier studies (Continued)

\begin{tabular}{lll}
\hline Plants name/voucher no. & Uses (present study) & Therapy/procedure of use \\
\hline $\begin{array}{l}\text { Syzygium cumini (L.) Skeels } \\
\text { UBKV FOR 169 }\end{array}$ & $\begin{array}{l}\text { Cough and cold, blood } \\
\text { dysentery, gastroenteritis }\end{array}$ & $\begin{array}{l}\text { Fruits are consumed to cure cough and } \\
\text { cold, blood dysentery and gastroenteritis. }\end{array}$
\end{tabular}

Earlier studies

Indigestion, dysentery, diarrhoea,

loose motion, stomach pain,

diabetes, anti-inflammatory,

sore throat, bronchitis, ulcers,

joint pain, piles $[10,11,25-27$,

$62,63,65,80,82]$

Nyctanthes arbor-tristis L. Fever UBKV FOR 339

Averrohoa carambola L. UBKV FOR 288

Piper nigrum L. UBKV FOR 268

Plumbago zeylanica

L. UBKV FOR 342

Arundo donax L. UBKV FOR 287

Bambusa vulgaris Schrad. UBKV FOR 291

Cynodon dactylon (L.) Pers. UBKV FOR 261

Eleusine indica (L.) Gaertn. UBKV FOR 314

Thysanolaena latifolia

Tonsillitis, boils, abortion

(Roxb. ex Hornem.) Honda UBKV FOR 355

Triticum aestivum

L. UBKV FOR 357

Polygonum dichotomum

Blume.

UBKV FOR 269

Polygonum hydropiper

L.

UBKV FOR 343

Cough and cold

Hydrocoel, fever

Headache

Night wetting vomiting, nose bleeding, increase lactation of domestic animals

Weakness of children

Hair loss

Baby crying
Leaf is either rubbed or its two teaspoon extract is consumed 2-3 days for curing fever. Flowers are also used as medicine following the same procedure.

Jaundice and liver problems

A glass of pulp juice is consumed three times a day in empty stomach for week to get a relief from jaundice.

Dried fruit powder in water solution is consumed for curing cough and cold.

Cuts and wounds, bleeding

Half a glass tender leaf extract are consumed daily early in the morning for a month to prevent hair fall.

Tender leaves of Opuntia ficus-indica and Polygonum dichotomum are mixed with milk and crushed together. Few drops are given for 2 times a day to stop baby crying.
Rheumatism, malaria, fever, cough and cold, fracture,

$[25,88]$

Asthma, cold and cough, rheumatism, constipation, eye infection, throat infection, indigestion, piles $[10,41,42,55$, $61,64,73,74,83]$

Eroenteritis, skin diseases, scabies, ulcer, diarrhoea, dysentery, indigestion, night blindness, abortion, leprosy $[55,62,64,73$, $74,84]$

Skin disease [19]

Shoot and leaf juice to control vomiting, skin disease, leprosy, piles, asthma, arthritis, burning urination, indigestion, cancer, eye and mouth problem, dysentery, blood purifier, control nose bleeding, anti-septic, snake bite, stop bleeding, wounds, miscarriage $[10,12,20,25,55,66$, $73,74,84]$

Boils, burns, tonsillitis, abortion [12]

Flatulence in goats [68]

Leaves and tender shoots against dental problem [10]

Blood coagulant, dysentery, gasteroenteritis, astringent [92, 93] 
Table 2 Ethnomedicinal uses of documented species and validated with earlier studies (Continued)

\begin{tabular}{lll}
\hline Plants name/voucher no. & Uses (present study) & Therapy/procedure of use \\
\hline Anthocephalus cadamba & Asthma & Leaves of Anthocephalus cadamba along \\
& & with alum powder are boiled together \\
(Roxb.) Miq. & and then the water after is taken half cup \\
UBKV FOR 285 & 2 times a day for 2 days and again after \\
& 1 month taken for 2 days in the same \\
& quantity of dose (i.e. should be continued \\
& in interval of every months which helps \\
& in curing asthma.
\end{tabular}

Aegle marmelos (L.) Corrêa UBKV FOR 218

Citrus limon (L.) Osbeck UBKV FOR 306

\section{Murraya koenigii (L.) \\ Sprengel}

UBKV FOR 266

Scoparia dulcis L. UBKV FOR 347

$\begin{array}{ll}\text { Ailanthus integrifolia Lam. } & \text { Fever } \\ \text { UBKV FOR 224 } & \\ \text { Datura metel L. } & \text { Diarrhoea, dental pain, ear } \\ \text { UBKV FOR 262 } & \text { pain, cut and } \\ & \text { wounds, fatigueness/ } \\ & \text { weakness of } \\ & \text { domestic animals }\end{array}$

Solanum indicum L. UBKV FOR 348

Solanum khasianum C.B. Clarke
UBKV FOR 230

Solanum melongena L. UBKV FOR 349

Solanum nigrum L. UBKV FOR 350
Stomach disorder, appetiser, dysentery

Vomiting, dysentery, of children after birth

Gastroenteritis

Piles, paralysis, diarrhoea, gastroenteritis blackening of nerve
Pneumonia, diabetes

Dental pain

Antiseptic

Dysentery, vomiting, asthma, bronchitis, fever, urinary discharge, cuts and wound
Earlier studies

Cholera, diarrhoea, dysentery, pyorrhoea, tooth brush, tooth pain, pimples, sores $[11,55,73,74]$

One glass of fruit pulp juice is taken three times a day to cure dysentery, diarrhoea and other stomach problems. It is also used as appetiser.

Leaf or root extract of $C$. lemon, bark of papaya and roots of Aegle marmelos are administered externally once a day for 3-4 days for curing blackening of nerve of children. Leaves and fruits are either smelled or consumed as raw to avoid vomiting.

Leaaves are consumed raw or as extract once a day in empty stomach to cure gasteroenteritis.

Leaf, stem, root or flower extract are consumed (2 teaspoons/day for 3 months) to cure piles. These parts are powdered and applied in the nose (2 times a day for 3 months) for treatment of paralysis. Plant (without root) extract solution is consumed in empty stomach ( 1 glass daily for 5 days) for curing diarrhoea and gasteroenteritis.

Resin extract from the plant is lightly burnt for fumigation of patient to get relieve from fever.

Fruits are roasted and consumed to cure diarrhoea. Root extract is mixed with water to feed domestic animals as general health tonic

The fruit pulp is mixed with coconut oil and heated which is then applied on ear after cooling twice a day for 2 days to get relief from pain. Unripe fruits are used to heal wound. Fruits or seeds crushed with mustard oil and heated and applied on teeth during morning for 2-3 days to get relief from pain.

Root beaten and made in the form of tablets to cure pneumonia. Fruits are cooked and eaten as vegetables for curing diabetes.

Fruits are burnt and placed on the teeth for getting relief from pain.

Fruits are cut and rubbed for a week to treat infection.

Asthma, boils, leprosy, diarrhoea, piles, cold and cough, joint pain, antirabies, gout, sores, dandruff, hair loss $[10,55,61,64,73,74,76]$

Leaf extract for black fever and diarrhoea, dysentery, diabetes, anaemia, vomiting, cut and wound, inflammation, appetiser $[10,25,26,61,72]$

Cough, burning sensation in pulmonary artery and veins, painful urination, diabetes, bronchitis, piles, cough, fever, tumour, boils, pneumonia, kidney stones, antiseptic, menstruation disorder [41, 55, $64,73,74,83,86,87]$

Ringworm in cattle [70]

Dental pain [41]

Wound, jaundice, abdominal swellings, stomach pain, head ache, fever, gonorrhoea, piles, dysentery, boils, eye infection $[27,35,42,55,73-76]$ 
Table 2 Ethnomedicinal uses of documented species and validated with earlier studies (Continued)

\begin{tabular}{|c|c|c|}
\hline Plants name/voucher no. & Uses (present study) & Therapy/procedure of use \\
\hline $\begin{array}{l}\text { Solanum xanthocarpum } \\
\text { Schrad. \& J.C. Wendl. } \\
\text { UBKV FOR } 362\end{array}$ & $\begin{array}{l}\text { Stomach disorder, blood } \\
\text { purifier, eye } \\
\text { problem }\end{array}$ & $\begin{array}{l}\text { Bark extract is boiled in water or fruits are } \\
\text { eaten after ripening for purifying blood } \\
\text { and cure gastroenteritis and dysentery. } \\
\text { Fruit juice is applied twice a day to } \\
\text { control eye problem. }\end{array}$ \\
\hline $\begin{array}{l}\text { Sterculia villosa Roxb. } \\
\text { UBKV FOR } 233\end{array}$ & Dysentery & - \\
\hline $\begin{array}{l}\text { Christella dentata (Forssk.) } \\
\text { Brownsey \& Jermy } \\
\text { UBKV FOR } 258\end{array}$ & Cuts and wound & $\begin{array}{l}\text { Leaves of Christella dentata, Justicia } \\
\text { adhatoda and Clerodendrum viscosum are } \\
\text { boiled and the solution is used to wash } \\
\text { wounds till healed. The plant is also used } \\
\text { as housefly and insects repellent. }\end{array}$ \\
\hline $\begin{array}{l}\text { Typha elephantina Roxb. } \\
\text { UBKV FOR } 358\end{array}$ & $\begin{array}{l}\text { Urine problem, purifies } \\
\text { breast milk, } \\
\text { internal bleeding }\end{array}$ & - \\
\hline $\begin{array}{l}\text { Lantana camara L. } \\
\text { UBKV FOR } 250\end{array}$ & Cough and cold & $\begin{array}{l}\text { Leaf extract is taken orally ( } 1-3 \text { spoon } 3 \\
\text { times a day) or the leaves are chewed or } \\
\text { consumed with rice to cure cough and } \\
\text { cold. }\end{array}$ \\
\hline Tectona grandis L. f. & Dysentery, piles, diabetes, & Young leaves are used as fodder. \\
\hline
\end{tabular}

Earlier studies

Seminal weakness [84]

Cuts and wounds [10]

Flowers used in bronchitis and urinary discharges; to promote hair growth along with coconut oil; leaf sap used to treat irregular menstrual cycle, burning sensation, kidney and skin disease, headache, tooth ache, swelling, stomach burning, skin irritation $[25,41,63,82,86]$

Bone fractures, cuts and wounds

Fire burnt skin, stomach disorder, body pain

Aloe vera $\mathrm{L}$. Burm.f UBKV FOR 279

Alpinia malaccensis

(Burm.f.) Roscoe

UBKV FOR 280

Curcuma caesia Roxb. UBKV FOR 259
Cuts and wounds, sores, digestive

Period of woman, chest pain, stomach pain, gastroenteritis, cuts and wounds
Half a glass leaf extract solution in water is taken twice a day (before meal in morning and after meal at night) for 3 days to treat fever before meal in the morning and after meal at night.

Whole plant is crushed and dressed on the fractured body part for $24 \mathrm{~h}$. The process is repeated for three times or till recovery. The therapy is same for domestic animals also.

Gout, fever, headache, cough and cold, sinusitis, diarrhoea, cardiac problems, rheumatism, fat burning, bedsore, wound, backbone pain, fracture, body swelling, joint swelling greying hair, memory vitaliser, stomach problem, swelling of joints, liver problem, jaundice $[10,12,41,42$, $48,55,61,63,64,66,73,74,77$, $78,86,91]$

Stem extract is used to treat broken bone $[25,41,67,82]$

Diabetes, general health, cough and cold, burns, cut and wound, fracture, arthritis, backbone pain, hepatitis, dermatitis $[22,25,66]$; stomach ache, piles, intestinal worms, eye disease, skin disease, allergy, tumours, liver tonic, purgative [69]

Inner part of the leaf is eaten as vegetables to help digestion.

Fruits are meshed with salt and consumed bu. woman to relief from periodic pain. It is taken in empty stomach (1-1.5) teaspoon for 3 days. Tuber extract is mixed with water and
Dried rhizome powder to treat skin disease, bone fracture, rhizome in rheumatic pains $[10,41,81]$ 
Table 2 Ethnomedicinal uses of documented species and validated with earlier studies (Continued)

\begin{tabular}{|c|c|c|c|}
\hline Plants name/voucher no. & Uses (present study) & Therapy/procedure of use & Earlier studies \\
\hline & & $\begin{array}{l}\text { taken to get relief from chest pain, } \\
\text { stomach pain and gastric. The extract is } \\
\text { applied on wounded part and dressed } \\
\text { for } 2 \text { days. }\end{array}$ & \\
\hline $\begin{array}{l}\text { Curcuma longa L. } \\
\text { UBKV FOR } 260\end{array}$ & $\begin{array}{l}\text { Lactation problem of } \\
\text { domestic animals, crack on } \\
\text { legs, cough and cold, fever, } \\
\text { stomach disorder, cuts } \\
\text { and wounds }\end{array}$ & $\begin{array}{l}\text { Flowers are crushed, mixed with feed } \\
\text { and fed to animals for increasing the milk } \\
\text { production. } \\
\text { Alum and lime is crushed to powder and } \\
\text { mixed with unripe rhizomes and placed } \\
\text { on ruptured portion of the skin for } \\
20 \text { min and then washed, dried and } \\
\text { messaged with coconut oil is used for } \\
\text { massage once a day for } 3 \text { days till } \\
\text { recovery. Fresfh rhizomes are roasted in } \\
\text { mustard oil for few minutes and applied } \\
\text { on wounds. The process continues till the } \\
\text { wound is healed. Alternately, the } \\
\text { rhizomes are boiled and consumed for } \\
\text { healing of wound and relief from fever, } \\
\text { cough and cold. Fresh rhizome extract is } \\
\text { added with water and a cup of the } \\
\text { solution is consumed after dinner for to } \\
\text { stomach disorders like gastric pain. This } \\
\text { solution is also consumes as health tonic. }\end{array}$ & $\begin{array}{l}\text { Dried and fresh rhizome powder } \\
\text { to treat cuts and wound, skin } \\
\text { disease, inflammation, cough and } \\
\text { cold, sores, boils, bone fracture, } \\
\text { swelling, muscular or body pains, } \\
\text { snake bite, stomach ache, bronco } \\
\text { asthma, antidote against poison, } \\
\text { blood purifier, jaundice and liver } \\
\text { disorder }[10,12,41,55,64,73 \text {, } \\
74,76]\end{array}$ \\
\hline $\begin{array}{l}\text { Zingiber zerumbet (L.) Sm. } \\
\text { UBKV FOR } 359\end{array}$ & $\begin{array}{l}\text { Snake bite, septic, cuts } \\
\text { and wounds, } \\
\text { back pain, pregnancy }\end{array}$ & $\begin{array}{l}\text { Rhizome is pasted and placed on any } \\
\text { bites or affected parts. Also used as } \\
\text { massage to remove body pain or back } \\
\text { pain. Rhizomes with leaves of Raulfia } \\
\text { serpentina and tubers of bedodgumi are } \\
\text { crushed together. This extract is mixed } \\
\text { with half cup of water and consumed } \\
\text { twice a day after meal for } 2 \text { days which } \\
\text { helps to boost pregnancy. }\end{array}$ & - \\
\hline
\end{tabular}

form as was also earlier reported [40, 43]. The preference for roots and rhizomes to prepare traditional remedies follows the scientific basis that roots generally contain high concentrations of bioactive compounds [44]. There are several reports on the administration of ethnomedicine by various authors $[11,12,20,22,41]$. It was also observed that herbal treatment is still preferred by the residents for bone fracture and dislocation over modern treatment. Senior citizens trust more upon traditional treatment system over the modern methods as they believe no side effect with the traditional ethnomedicine. Similar observations were also documented by [10]. The present study documented 140 ethnomedicinal plant species from North Bengal, of which 62 species were also reported in earlier studies [19, 20, 39, 45-49] from north India with similar ethnomedicinal uses. The medicinal uses of the species also reported from north India is compared with our study and is presented in Table 4.

\section{Use value}

The use value of a species indicates the ethnobotanical importance of a particular species in an area or by a community. The higher the value for a species, the higher is the importance of the species i.e. were most utilised or exploited. The use value range found was $0.01-0.13$ (Table 1) The highest use value of 0.13 was estimated for Centella asiatica, followed by Terminalia arjuna and Oroxylum indicum each with 0.09; Musa sp., Ocimum sanctum and Leucas aspera each with 0.08; and Dillenia indica with use value of 0.07 . Use values of 0.05 were found for Justicia adhatoda, Mangifera indica, Diplazium esculentum, Dioscorea belophylla and Azadirachta indica, while Terminalia bellirica, Morus alba, Moringa oleifera, Cynodon dactylon and Aegle marmelos had a use value of 0.06 . Use value on medicinal ethnobotanical plants was also earlier reported and similar conclusions made [50-52]. These species were utilised because of their therapeutic uses in multiple diseases and were abundantly available in wild and were also all grown in the home gardens.

\section{Conservation status}

Various authors have feared that these ethnomedicinal species are disappearing from the wild due to 
Table 3 Number of species used as ethnomedicine for a particular disease/ailment

\begin{tabular}{|c|c|}
\hline Human diseases/ailments & $\begin{array}{l}\text { Species } \\
\text { used }\end{array}$ \\
\hline $\begin{array}{l}\text { Stomach-related disorder (stomach problem, dysentery, } \\
\text { diarrhoea, indigestion, stomach pain) }\end{array}$ & 40 \\
\hline Cuts and wounds & 27 \\
\hline $\begin{array}{l}\text { Pain (joints pain, body pain, chest pain, neck pain, tooth } \\
\text { pain) }\end{array}$ & 25 \\
\hline Jaundice/liver problem & 19 \\
\hline Cough and cold & 18 \\
\hline Gastroenteritis & 17 \\
\hline Fever & 16 \\
\hline Skin-related disease & 13 \\
\hline Diabetes & 12 \\
\hline Appetiser and ulcer & 9 each \\
\hline Headache, piles,asthma and bleeding (internal, nose) & 8 each \\
\hline Burns & 7 \\
\hline Swelling and pneumonia & 6 each \\
\hline $\begin{array}{l}\text { Hair loss/fall/dandruff problems, blood pressure and } \\
\text { paralysis }\end{array}$ & 5 each \\
\hline Vomiting and bite (dog, bees, snake) & 4 each \\
\hline $\begin{array}{l}\text { Urine disorder, blood purifier and blood disease, sore } \\
\text { throat and sores, tonsil }\end{array}$ & 3 each \\
\hline $\begin{array}{l}\text { Small/chicken pox, malaria, hydrocoel, tumours, cancer, } \\
\text { septic, boils, eye infection/conjunctivitis/red eye, clearing } \\
\text { stool, reduce weight, tuberculosis, heart problems, night } \\
\text { wetting, periodic problems of women }\end{array}$ & 2 each \\
\hline $\begin{array}{l}\text { Typhoid, baby cry, dehydration, bronchitis, urinary } \\
\text { discharge, abortion, gall bladder stone, pulmonary/lungs } \\
\text { problem, anaemia, purifies breast milk, pregnancy, } \\
\text { blackening of nerve, cholesterol, alcoholic medicine, } \\
\text { fatigueness, body severing, body massager }\end{array}$ & 1 each \\
\hline \multicolumn{2}{|l|}{ Veterinary/disease/ailments } \\
\hline Tongue/mouth disease and lactation problem & 2 each \\
\hline $\begin{array}{l}\text { Stomach worm, cough, diarrhoea, cuts and wounds, } \\
\text { fatigueness/weakness and appetiser }\end{array}$ & 1 each \\
\hline
\end{tabular}

unsustainable exploitation of these species and destruction of habitat of these species due to deforestation. Workers had reported the conservation status of medicinal plants of the Terai region [53] and Darjeeling Himalayas $[54,55]$ of West Bengal. In this study, the documented plant species were compared with these reports for the conservation status of these plant species. It was found that 38 ethnomedicinal plant species documented in this study were reported of their conservation status from Darjeeling Himalayas also (Table 1). According to the Darjeeling studies, plant species were classified as abundant, common, endangered, frequent, planted, rare and sparse and the number of documented species falling in these categories were four, five, three, five, five, three and 13, respectively (Table 1 ). Another study from the Terai region of West Bengal [53] also classified the plant species in terms of conservation status like rare, frequent and sparse, and 31 ethnomedicinal plant species documented in this study (Table 1) were categorised according to their conservation status in the Terai study.

Many plants growing wild and traditionally used are endemic and have become rare, threatened or endangered [56, 57], so they need to be conserved. Reserves of ethnomedicinal plants in developing countries are diminishing and in danger of extinction as a result of growing trade demands for cheaper products and new plant-based therapeutic markets in preference to more expensive target-specific drugs and biopharmaceuticals [11]. Genetic biodiversity of ethnobotanic plants is continuously under the threat of extinction as a result of commercial exploitation, grazing, environment-unfriendly harvesting techniques, loss of growth habitats and unmonitored trade of medicinal plants [58-61] This is because ethnomedicinal plants were freely harvested by users from their immediate environment either for their own use or traded domestically [62, 63]. The harvesting of these multiple use species can put them under threat [62] but can also lead to better chances for their conservation [63] especially through home gardens.

\section{Conclusions}

The Chilapatta Reserve Forest and its fringe areas are rich in biodiversity of ethnomedicinal plant species. A total of 140 plant species represented by 116 genera and 65 families were documented for medicinal purpose. Majority of the plant species (108) have more than one part that was medicinally important. The indigenous communities mainly used the leaf of the plant for their ethnomedicinal uses. The curing of 58 human diseases from these documented plant species itself explains the importance of this area in national and international interest. Gastric problem is common in this area and 40 plant species were used for the treatment of this disease. Centella asiatica and Rauvolfia serpentina were the most valuable species in terms of its maximal use with higher use value. Comparison with the previous regional ethnomedicinal studies, we observed that 30 plant species documented in the present study were not having earlier reports. This means that the use of 30 plant species have been reported for the first time from this area for ethnomedicinal use. It was found that 38 ethnomedicinal plant species documented in this study were earlier reported for their conservation status from adjoining areas 
Table 4 Medicinal uses of the species in present study versus north Indian studies

\begin{tabular}{|c|c|}
\hline Scientific name & North Indian studies \\
\hline Abroma augusta (L.) L.f. & Urinary infection, bronchitis, diabetes [45] \\
\hline Areca catechu L. & Boils and skin eruptions, diarrhoea and dysentery, bleeding from nose, chest pain $[45,46]$ \\
\hline Acacia nilotica (L.) Delile & Jaundice, burns, headache, cholera, diarrhoea, dysentery $[39,45]$ \\
\hline Acorus calamus L. & Dysentery and diarrhoea [46] \\
\hline Aegle marmelos (L.) Corrêa & Fever, diarrhoea, dysentery, gastroenteritis, sun burn $[39,45,46]$ \\
\hline Ageratum conyzoides L. & Muscular pain, cuts, wounds, stop bleeding, piles, snake bite $[45,48]$ \\
\hline Aloe vera $\mathrm{L}$. Burm.f. & Stomach ache, piles, intestinal worms, eye disease, skin disease, tumours [46] \\
\hline Alstonia scholaris (L.) R. Br. & $\begin{array}{l}\text { malaria, pneumonia, stomach a } \\
\text { che [45]; bark to treat snake bite, asthma and cardiac troubles, latex is applied to ulcers, sores and } \\
\text { tumours [46] }\end{array}$ \\
\hline Andrographis paniculata (Burm.f.) Wall. ex Nees & Malaria, fever, stomach problems, worms, dysentery $[45,46]$ \\
\hline Annona squamosa L. & $\begin{array}{l}\text { Diarrhoea, dysentery, indigestion, dandruff, lice, spinal problem [45, 46]; Constipation and abdominal } \\
\text { swelling of animals [47] }\end{array}$ \\
\hline Anthocephalus cadamba (Roxb.) Miq. & Cholera, dysentery, pimples [45] \\
\hline Artocarpus hetrophyllus Lam & Cough, leprosy, ulcers [46] \\
\hline Arundo donax L. & Skin disease [19] \\
\hline Asparagus racemosus Willd. & Bleeding nose, epilepsy, arthritis [39, 45, 49]; fever and constipation of domestic animals [47] \\
\hline Azadirachta indica A. Juss & Wounds, cold, diabetes, cancer $[39,45]$ \\
\hline Basella alba Stewart. & Constipation, nose sorosis [45] \\
\hline Bombax ceiba L. & Tooth ache, pimples, snake bite $[45,46]$ \\
\hline Calotropis procera $\mathrm{R}$. Br. & $\begin{array}{l}\text { Pox, cholera, malaria, boils, skin disease, pregnancy, digestive tonic, indigestion of domestic animals } \\
{[39,45-47]}\end{array}$ \\
\hline Carica papaya L. & Dysentery, tooth ache [48] \\
\hline Centella asiatica (L.) Urb. & Leprosy, cough ulcer [46] \\
\hline Cissus quadrangularis L. & Stem extract is used to treat broken bone [46] \\
\hline Citrus limon (L.) Osbeck & Fever and mouth disease of animals [46] \\
\hline Clerodendrum viscosum Vent. & Tumour, malaria, snake bite, boils, burns, cut and wounds $[45,63]$ \\
\hline Colocasia esculenta (L.) Schott & Stop bleeding, removes redness of skin [46] \\
\hline Curcuma longa $\mathrm{L}$. & $\begin{array}{l}\text { Cuts and wound, bone fracture, swelling, muscular or body pains, snake bite, stomach ache, blood } \\
\text { purifier }[46,49]\end{array}$ \\
\hline Cynodon dactylon (L.) Pers. & Dysentery, snake bite, stop bleeding, wounds, $[45,49]$ \\
\hline Datura metel L. & Asthma, boils, leprosy, diarrhoea, piles $[45,47]$; cold, pneumonia of cattle $[39,47]$ \\
\hline Ficus benghalensis $\mathrm{L}$. & Diabetes, hair vitalizer, stomach pain, $[39,45]$; diarrhoea and dysentery of domestic animals [47] \\
\hline Ficus carica L. & Boils, skin disease, constipation $[20,45]$ \\
\hline Ficus hispida L. f. & Mouth ulcer [45] \\
\hline Ficus racemosa $\mathrm{L}$. & Piles, boils, diarrhoea, dysentery, $[45,46]$ \\
\hline Hibiscus rosa sinensis $\mathrm{L}$. & Fever, abortion, burning sensation, twitching $[39,46,49]$ \\
\hline Jatropha curcas L. & Branches used as tooth brush to remove tooth pain [63] \\
\hline Justicia adhatoda L. & Cough, bronchitis, asthma, malaria $[45,63]$ \\
\hline Mangifera indica $\mathrm{L}$. & Dysentery, ear ache, vomiting, heat stroke, digestion $[39,46]$ \\
\hline Melia azedarach L. & Skin disease, head ache, stomach worm [46] \\
\hline Mimosa pudica L. & Dental pain, head ache, wounds placenta prolepses $[45,47]$ \\
\hline Momordica dioica Roxb. ex Willd. & Diabetic, breast swelling [45] \\
\hline Moringa oleifera $\mathrm{L}$. & $\begin{array}{l}\text { Diarrhoea, dysentery [39]; flowers to restore health and proper urination, fruits for paralysis and } \\
\text { diseases of the liver [46] }\end{array}$ \\
\hline Morus alba L. & Fruits good for kidney and liver [46] \\
\hline
\end{tabular}


Table 4 Medicinal uses of the species in present study versus north Indian studies (Continued)

\begin{tabular}{|c|c|}
\hline Scientific name & North Indian studies \\
\hline Murraya koenigii (L.) Sprengel & Fever, diarrhoea, dysentery, appetiser [46] \\
\hline Nyctanthes arbor-tristis L. & Fever, cough dysentery, leaves for indigestion $[45,46]$ \\
\hline Oroxylum indicum (L.) Benth. & Cough, mouth sore, ulcer, bronchial asthma, joint pain, appetiser [46] \\
\hline Plumbago zeylanica L. & Diarrhoea, indigestion [45] \\
\hline Pongamia pinnata L. & Malaria, fever, piles, cough, skin disease and boils [46] \\
\hline Psidium guajava $\mathrm{L}$. & Wounds, fever, diarrhoea ulcer, vomiting, $[39,46,47]$ \\
\hline Punica granatum L. & Diarrhoea, indigestion [46] \\
\hline Rauvolfia serpentine (L.) Benth ex Kurz. & Insanity, blood pressure, intestinal disorder, vomiting, snake bite $[45,46]$ \\
\hline Ricinus communis L. & Wounds (human and animal), joint pain, sores, boils, burns, rheumatic swelling, $[45-47,70]$ \\
\hline Shorea robusta Gaertn f. & Diarrhoea, dysentery, burning sensation, chest pain, pox, ear pain $[45,48]$ \\
\hline Solanum khasianum C.B. Clarke & Dental pain and decay [46] \\
\hline Solanum nigrum L. & $\begin{array}{l}\text { Wound, jaundice, abdominal swellings, stomach pain, head ache, fever, gonorrhoea, piles, dysentery, } \\
\text { boils, eye infection }[20,45,47]\end{array}$ \\
\hline Syzygium cumini(L.) Skeels & Dysentery, sore throat, bronchitis, ulcers, joint pain $[39,46]$ \\
\hline $\begin{array}{l}\text { Tabernaemontana divaricata (L.) R. Br. ex Roem. } \\
\text { \& Schult. }\end{array}$ & Eye disease, appetiser, dental pain [46] \\
\hline Tagetes erecta L. & Hydrophobia [39] \\
\hline Tectona grandis L. f. & Bronchitis, urinary discharges, headache, swelling, stomach burning, [46] \\
\hline Terminalia arjuna (Roxb.) Wight \&Arn. & Dysentery, tumours, asthma, fractured bones, diabetes, anaemia, hypertension [46] \\
\hline Terminalia bellirica (Gaertn.) Roxb. & Skin disease, cold, constipation, cuts and wounds, piles, dropsy, leprosy, headache, $[45,46,48]$ \\
\hline Terminalia chebula Retz. & Constipation, stomach disorder/pain, urinary problem, cold respiratory troubles $[45,48]$ \\
\hline $\begin{array}{l}\text { Tinospora cordifolia (Willd.) Miers ex Hook. f. \& } \\
\text { Thom. }\end{array}$ & Jaundice, fever, diarrhoea, dysentery, malaria, appetiser $[45,46]$ \\
\hline Trigonella foerum-graecum L. & Easier pregnancy, foot and mouth disease of animals, diarrhoea of animals, appetiser, [39, 47] \\
\hline Vitex negundo L. & Headache, rheumatism, body swelling, joint swelling, diarrhoea of cattle $[39,46]$ \\
\hline
\end{tabular}

including endangered, frequent, planted, rare and sparse. The communities should be encouraged with improved cultivation techniques of commercially viable ethnomedicinal species through capacity building, timely policy intervention along with strong market linkage. This will ensure income generation and livelihood improvement and ultimate conservation of these species. The present information may serve as a baseline data to initiate further research for newly reported species for new compounds and biological activities which can be of immense value for societies to survive.

\section{Acknowledgements}

The authors thank all the participants in the study for providing ethnomedicinal information.

\section{Funding}

This study is self-financed.

Availability of data and materials

The data and material is available from the corresponding author.

\section{Authors' contributions}

$\mathrm{SB}, \mathrm{NP}, \mathrm{GS}$, and $\mathrm{V}$ designed the study, collected the data and developed the manuscript. MK, SC, RWB and AJR improved the manuscript and restructured the data analysis. All authors read and approved the final manuscript.

\section{Ethics approval and consent to participate}

Prior oral informed consent was obtained from the local communities as well as from all individual participants.

\section{Consent for publication}

All participants gave consent for publication.

\section{Competing interests}

The authors declare that they have no competing interests.

\section{Publisher's Note}

Springer Nature remains neutral with regard to jurisdictional claims in published maps and institutional affiliations.

\section{Author details}

'Department of Forestry, Uttar Banga Krishi Vishwavidyalaya, Cooch Behar, West Bengal, India. ${ }^{2}$ Department of Forestry and Natural Resources, HNB Garhwal University, Srinagar Garhwal, Uttarakhand, India. ${ }^{3}$ Saving Knowledge, Casilla, 13092 La Paz, Bolivia. ${ }^{4}$ Mekelle University, Mekelle, Tigray, Ethiopia. 
Received: 10 May 2017 Accepted: 3 January 2018

\section{Published online: 26 January 2018}

\section{References}

1. Van der Merwea D, Swana GE, Botha CJ. Use of ethnoveterinary medicinal plants in cattle by Setswana-speaking people in the Madikwe area of the North West Province of South Africa. J S Afr Vet Assoc. 2001;72:189-96.

2. Lewis WH, Elwin Lewis MP. Medical botany plants affecting human health. New York: Wiley; 2003. p. 812.

3. IwU MM. African medicinal plants in the search for new drugs based on ethnomedicinal leads. In: Chadwick DJ, Marsh J, editors. Ethnobotany and the search for new drugs, Ciba foundation symposium 185. Chichester: Wiley; 1994. p. 116-29.

4. Reddy BM. Wild edible plants of Chandrapur district, Maharashtra, India. Indian J Nat Prod Resour. 2012;3:110-7.

5. Payyappallimana U, Fadeeva Z. Traditional knowledge and biodiversity. Yokohama: United Nations University-IAS; 2013.

6. Narzary H, Brahma S, Basumatary S. Wild edible vegetables consumed by BodoTribe of Kokrajhar District (Assam), North-East India. Arch Appl Sci Res. 2013;5:182-90

7. Jain $D L$, Baheti $A M$, Jain $S R$, Khandelwal KR. Use of medicinal plants among tribes in Satpuda region of Dhule and Jalgaon districts of Maharashtra-an ethnomedicinal survey. Indian J Tradit Knowl. 2010;9:152-7.

8. Jeyaprakash K, Ayyanar M, Geetha KN, Sekar T. Traditional uses of medicinal plants among the tribal people in Theni districts (Western Ghats), Southern India. Asian Pac J Trop Biomed. 2011;1:S20-5.

9. Kumar B, Vijayakumar M, Govindarajan R, Pushpangadan P. Ethnopharmacological approaches to wound healing —exploring medicinal plants of India. J Ethnopharmacol. 2007;114:103-13.

10. Shukla G, Chakravarty S. Ethnomedicinal plant use of Chilapatta reserved forest in West Bengal. Indian Forester. 2012;138:1116-24.

11. Biswakarma S, Sarkar BC, Shukla G, Pala NA, Chakravarty S. Traditional application of ethnomedicinal plants in Naxalbari area of West Bengal, India. Int J Usufruct Manag. 2015;16:36-42.

12. Sarkar BC, Biswakarma S, Shukla G, Pala NA, Chakravarty S. Documentation and utilization pattern of ethnomedicinal plants in Darjeeling Himalayas, India. Int J Usufruct Manag. 2015:16:3-11.

13. Kar A, Goswami NK, Saharia D. Wild edible plants sold in the local market of Garo hills, Meghalaya. J Frontline Res Arts Sci. 2012;2:69-78.

14. Suresh CP, Bhutia KD, Shukla G, Pradhan K, Chakravarty S. Free list of wild edible fruit species of Sikkim Himalayas and their uses. Proceedings of the Second International Symposium on Minor Fruits and Medicinal Plants for Better Lives 2013; pp.17-37.

15. Geng Y, Zhang Y, Ranjitkar S, Huai H, Wang Y. Traditional knowledge and its transmission of wild edibles used by the Naxi in Baidi Village, northwest Yunnan province. J Ethnobiol Ethnomed. 2016;12:10-30.

16. Ferreira FS, Brito SV, Ribeiro SC, Almeido WO, Alves RRN. Zoo therapeutics utilized by residents of the community PocoDantas, Crato-CE, Brazil. J Ethnobiol Ethnomed. 2009;5:21.

17. Phillips O, Gentry AH, Reynel C, Wilkin P, Galvez-Durand CB. Quantitative ethnobotany and Amazonian conservation. Conserv Biol. 2002;8:225-48.

18. Mekonen T, Giday M, Kelbessa E. Ethnomedicinal study of home garden plants in Sebeta-Awas District of the Oromia Region of Ethiopia to assess use, species diversity and management practices. J Ethnobiol Ethnomed. 2015;11:64-76

19. Ikram S, Bhatti KH, Parvaiz M. Ethnomedicinal studies of aquatic plants of district Sialkot, Punjab (Pakistan). J Med Plants Stud. 2014;2:58-63.

20. Amjad MS, Arshad M, Qureshi R. Ethnomedicinal inventory and folk uses of indigenous plants from PirNasoora National Park, Azad Jammu and Kashmir. Asian Pac J Trop Biomed. 2015;5:234-41.

21. Hamidou A, Boube M, Mahamane L, Ali M, Mahamane S, Bellefontaine R. Uses and preferences of woody species in two protected forests of Dan Kada Dodo and Dan Gado in Niger. J Hortic For. 2015;7:149-59.

22. Jennings HM, Merrell J, Thompson JL, Heinrich M. Food or medicine? The food-medicine interface in households in Sylhet. J Ethnopharmacol. 2015;167:97-104.

23. Li F, Zhuo J, Liu B, Jarvis D, Long C. Ethnomedicinal study on wild plants used by Lhoba people in Milin County, Tibet. J Ethnobiol Ethnomed. 2015;11:23-33.

24. Łuczaj L, Stawarczyk K, Kosiek T, Pietras M, Kujawa A. Wild food plants and fungi used by Ukrainians in the western part of the Maramureş region in Romania. Acta Soc Bot Pol. 2015;84:339-46.
25. Singh U, Bharti AK. Ethnomedicinal study of plants of Raigarh area, Chhattisgarh, India. Int Res J Biol Sci. 2015;4:36-43.

26. Anand SP, Deborah S. Enumeration of wild edible fruits from Boda hills and Kolli hills. Int J Appl Biol Pharm Technol. 2016;7:96-102.

27. Shiracko N, Owuor BO, Gakuubi MM, Wanzala W. A survey of ethnobotany of the AbaWanga people in Kakamega county, western province of Kenya. Indian J Tradit Knowl. 2016;15:93-102.

28. Johnson LM, Hunn ES. Introduction. In: Johnson LM, Hunn ES, editors. Landscape ethnoecology: concepts of biotic and physical space. New York and Oxford: Berghahn Books 9; 2010. p. 1-11.

29. Frei B, Sticher O, Heinrich M. Zapotec and Mixe use of tropical habitats for securing medicinal plants in Mexico. Econ Bot. 2000;54:73-81.

30. Finerman R, Sackett R. Using home gardens to decipher health and healing in the Andes. Med Anthropol Q. 2003;17:459-82.

31. Sõukand R, Kalle R. Herbal landscape: the perception of the landscape as a source of medicinal plants. Trames. 2010;14(64/59):207-26.

32. Agelet $\mathrm{A}$, Bonet MA, Vallès J. Home gardens and their role as a main source of medicinal plants in mountain regions of Catalonia (Iberian Peninsula). Econ Bot. 2000;54:295-309.

33. Stepp JR, Moerman DE. The importance of weeds in ethnopharmacology. J Ethnopharmacol. 2001;75:19-23.

34. Thomas E, Vandebroek I, Van Damme P, Goetghebeur P, Douterlungne D, Sanca S, Arrázola S. The relation between accessibility, diversity and indigenous valuation of vegetation in the Bolivian Andes. J Arid Environ. 2009;73:854-61.

35. Bose D. An ethno-medicobotanical investigation among Rava tribe of Jalpaiguri district .NBU. J Plant Sci. 2011;5:61-5.

36. Khan FM. Ethno-veterinary medicinal usage of flora of greater Cholistan desert (Pakistan). Pak Vet J. 2009;29:75-80.

37. Selvaraju A, Ayyanar M, Rathinakumar SS, Sekar T. Plants used in ethnoveterinary medicine by Malayali tribals in Salem district of Tamil Nadu, India. Med Plants. 2011;3:1-7.

38. Devendrakumar D, Anbazhagan M. Ethnoveterinary medicinal plants used in Perambalur District, Tamil Nadu. Res Plant Biol. 2012;2:24-30.

39. Verma RK. An ethnomedicinal study of plants used for the treatment of livestock diseases in Tikamgarh District of Bundelkhand, Central India. Asian Pac J Trop Biomed. 2014;4:S460-7.

40. Uprety Y, Poudel RC, Gurung J, Chettri N, Chaudhary RP. Traditional use and management of NTFPs in Kanchenjunga Landscape: implications for conservation and livelihoods. J Ethnobiol Ethnomed. 2016;12:19-77.

41. Bose D, Ghosh Roy J, Das Mahapatra (Sarkar) S, Datta T, Das Mahapatra S, Biswas H. Medicinal plants used by tribals in Jalpaiguri district, West Bengal, India. J Med Plants Stud. 2015;3:15-21.

42. Ignacimuthu S, Ayyanar M, SankaraSivaraman K. Ethnobotanical investigations among tribes in Madurai district of Tamil Nadu (India). J Ethnobiol Ethnomed. 2006;2:25-31. https://doi.org/10.1186/1746-4269-2-25.

43. Rokaya MB, Uprety Y, Poudel RC, Timsina B, Münzbergová Z, Asselin H, Tiwari A, Shrestha SS, Sigdel SR. Traditional uses of medicinal plants in gastrointestinal disorders in Nepal. J Ethnopharmacol. 2014;158:221-9.

44. Moore PD. Trials in bad taste. Nature. 1994;370:410-1.

45. Singh A, Dubey NK. An ethnomedicinal study of medicinal plants in Sonebhadra district of Uttar, Pradesh, India with reference to their infection by foliar fungi. J Med Plants Res. 2012;6:2727-46.

46. Mathur A, Joshi H. Ethnobotanical studies of the Terai region of Kumaun, Uttarakhand, India. Ethnobot Res Appl. 2013;11:175-203.

47. Dar BA, Verma RK, Haq A. Ethnoveterinary value of some plant species utilized by rural people of Jhansi district, Bundelkhand region. Res J Agri Sci. 2011;2:321-4.

48. Singh A, Singh GS, Singh PK. Medico-ethnomedicinal inventory of Renukoot forest division of district Sonbhadra, Uttar Pradesh, India. Indian J Nat Prod Resour. 2012;3:448-57.

49. Phondani PC, Maikhuri RK, Rawat LS, Farooquee NA, Kala CP, Vishvakarma SCR, Rao KS, Saxena KG. Ethnobotanical uses of plants among the Bhotiya tribal communities of Niti valley in Central Himalaya, India. Ethnobot Res Appl. 2010;8:233-44.

50. Sharma J, Gairola S, Gaur RD, Painuli RM. The treatment of jaundice with medicinal plants in indigenous communities of the sub-Himalayan region of Uttarakhand, India. J Ethnopharmacol. 2012;143:262-91.

51. Sharma J, Gairola S, Gaur RD, Painuli RM, Siddiqi TO. Ethnomedicinal plants used for treating epilepsy by indigenous communities of sub-Himalayan region of Uttarakhand, India. J Ethnopharmacol. 2013;150:353-70. 
52. Sharma J, Gairola S, Gaur RD, Siddiqi TO, Painuli RM. Plants used for treatment of dysentery and diarrhoea by the Bhoxa community of district Dehradun, Uttarakhand, India. J Ethnopharmacol. 2013;150:969-1006.

53. Shukla G. Biomass production and vegetation analysis of Chilapatta reserve forest ecosystem of West Bengal. Pundibari West Bengal: Ph. D. Thesis. Uttar Banga Krishi Viswavidyalaya; 2010.

54. Chhetri DR, Basnet D, Chou PF, Kalikotay S, Chhetri G, Parajuli S. Current status of ethnomedicinal plants in the Darjeeling Himalaya. Curr Sci. 2005;89:264-8.

55. Yonzone R, Bhujel RB, Rai S. Genetic resources, current ecological status and altitude wise distribution of medicinal plants diversity of Darjeeling Himalaya of West Bengal, India. Asian Pac J Trop Med. 2012;2:S439-45.

56. Pandey AR. Conservation of biodiversity: present status \& future strategy. In: Pandey AK, editor. Taxonomy and biodiversity. Delhi: CBS Publishers; 1995. p. 44-51.

57. Bhujel RB. Studies on the dicotyledonous flora of Darjeeling district. Ph. D. Thesis. Siliguri: North Bengal University; 1996.

58. Farooquee NA, Saxena KG. Conservation and utilization of medicinal plants in high hills of Central Himalaya. Environ Conserv. 1996;23:75-80.

59. Kala CP. Indigenous knowledge of Bhotia tribal community on wool dying and its present status in the Garhwal Himalaya, India. Curr Sci. 2002;83:814-7.

60. Maikhuri RK, Nautiyal KS, Rao KS, Semwal RL. Indigenous knowledge of medicinal plant and wild edibles among the three tribal sub-communities of the Central Himalaya, India. Indigenous Knowl Dev Monit. 2000;8:7-13.

61. Ghosh A. Ethnomedicinal plants used in West Rahrr region of West Bengal. Nat Prod Radiance. 2008:75:461-5.

62. Dhillion SS, Shrestha PM. Conservation needs and regulations for locally managed forests in the highlands of Dolakha district, Nepal. In: Salleh $\mathrm{H}_{\text {, }}$ Aziz S, editors. Environmental and development aspects of natural resource management in mountains. Singapore: Pelanduk Press; 2005.

63. Etkin NL. Local knowledge of biotic diversity and its conservation in rural Hausaland, Northern Nigeria. Econ Bot. 2002;56:73-88.

64. Rai MB. Medicinal plants of Tehrathum District, Eastern Nepal. Our Nature. 2003;1:42-8.

65. Bandyopadhyay S, Mukherjee SK. Wild edible plants of Koch Bihar district, West Bengal, India. Nat Prod Radiance. 2009;8:64-72.

66. Murad W, Azizullah A, Adnan M, Tariq A, Khan KU, Waheed S, Ahmad A Ethnomedicinal assessment of plant resources of Banda Daud Shah, District Karak, Pakistan. J Ethnobiol Ethnomed. 2013:9:77-86.

67. Sanghi SB. Study of some ethno-veterinary medicinal plants of Tendukheda district Narsinghpur, Madhya Pradesh. Life Sciences Leaflets. 2014:55:1-5.

68. Takhar HK. Folk herbal veterinary medicines of southern Rajasthan. Indian J Tradit Knowl. 2004;3:407-18.

69. Verma P, Mathur AK, Jain SP, Mathur A. In vitro conservation of twentythree over exploited medicinal plants belonging to the Indian sub continent. Sci World J. 2012;12 https://doi.org/10.1100/2012/929650.

70. Malla B, Chhetri RB. Ethnoveterinary practices of some plant species by ethnic people of Parbat district, Nepal. Kathmandu Univ J Sci Eng Technol. 2012:8:44-50.

71. Chettri D, Moktan S, Das AP. Ethnomedicinal studies on the tea garden workers of Darjeeling Hills. Pleione. 2014;8:124-32.

72. Padal SB, Chandrasekhar P, Satyavathi K. Ethnomedicinal investigation of medicinal plants used by the tribes of PedabayaluMandalam, Visakhapatnam District, Andhra Pradesh, India. Int J Comput Eng Res. 2013;3:8-13.

73. Yonzone R, Rai S, Bhujel RB. Ethnomedicinal and aromatic plant diversity and resources of Darjeeling district of eastern Himalaya in India. Int J Adv Pharm Res. 2012:3:859-71.

74. Yonzone R, Rai S, Bhujel RB. Genetic diversity of ethnobotanical and medicinal plants resources of Darjeeling district, West Bengal, India. Int J Adv Pharm Res. 2012;3:713-29.

75. Joshi $K$, Joshi $R$, Joshi AR. Indigenous knowledge and uses of medicinal plants in Macchegaun, Nepal. Indian J Tradit Knowl. 2011;10:281-6.

76. Singh A, Singh RK, Bhardwaj R, Singh AK. Adaptations of culturally and nutritionally important traditional foods in Eastern Himalaya: a case study with Adi women of Arunachal Pradesh. Indian J Tradit Knowl. 2012;11:623-33.

77. Samar R, Shrivastava PN, Jain M. Ethnomedicinal study of traditional medicinal plants used by tribe of Guna District, Madhya Pradesh, India. Int J Curr Microbiol App Sci. 2015;4:466-71.
78. Singh AG, Kumar A, Tewari DD. An ethnomedicinal survey of medicinal plants used in Terai forest of western Nepal. J Ethnobiol Ethnomed. 2012;8:19-32

79. Simbo DJ. An ethnomedicinal survey of medicinal plants in Babungo, Northwest Region, Cameroon. J Ethnobiol Ethnomed. 2010;6:8-14.

80. Shrivastava S, Kanungo VK. Ethnomedicinal survey of Surguja district with special reference to plants used by Uraon tribe in treatment of diabetes. Int $J$ Herb Med. 2013;1:127-30.

81. Malla S, Shukla G, Chakravarty S. Utilization and conservation of wild plants by the tribal communities of Tripura. Indian Forester. 2012;138:1002-7.

82. Ghosh SK, Guria N, Sarkar A, Ghosh A. Traditional herbal remedies for various ailments within the rural communities in the district of Bankura and Purulia, West Bengal, India. Int J Pharm Pharm Sci. 2013;5:195-8.

83. Jose T, Sebastian A, Antony VT. Ethnomedicinal study of traditional medicinal plants used by indigenous people in North Kerala. Indian J Appl Res. 2015;5:184-6.

84. Das HB, Majumdar K, Datta BK, Ray D. Ethnomedicinal uses of some plants by Tripuri and Reang tribes of Tripura. Nat Prod Radiance. 2009:8:172-80.

85. Choudhary K, Singh M, Pillai U. Ethnobotanical survey of Rajasthan-an update. Am-Eurasian J Bot. 2008;1:38-45.

86. Sinhababu A, Banerjee A. Ethno-botanical study of medicinal plants used by tribals of Bankura district, West Bengal, India. J Med Plants Stud. 2013:1:98-104.

87. Mondal T, Mondal D, Mondal S. Conservation strategies of medicinal plants with reference to North Bengal for a better tomorrow. J Todays Biol Sci Res Rev. 2013;2:83-8.

88. Mondal T, Samanta S. An ethnomedicinal survey on medicinal plants of Ghatal block, West Midnapur District, West Bengal, India. Int J Curr Res Biosci Plant Biol. 2014;1:35-7.

89. Achar KG, Somashekhara Boosanur V, Shivanna MB. Ethno-medico-botanical knowledge of Tipturtaluk in Tumkur district of Karnataka, India. Indian J Tradit Knowl. 2015:1:147-54

90. Konsam S, Thongam B, Handique AK. Assessment of wild leafy vegetables traditionally consumed by the ethnic communities of Manipur, northeast India. J Ethnobiol Ethnomed. 2016;12:9-23.

91. Kumar A, Avasthe RK, Shukla G, Pradhan Y. Ethnobotanical edible plant biodiversity of Lepcha tribes. Indian Forester. 2012;138:798-803.

92. Hong H, Zhuo J, Lei Q, Zhou J, Ahmed S, Wang C, Long Y, Li F, Long C. Ethnobotany of wild plants used for starting fermented beverages in Shui communities of southwest China. J Ethnobiol Ethnomed. 2015:11:42-62.

93. Tiță I, Mogoşanu GD, Tiță MG. Ethnomedicinal inventory of medicinal plants from the south-west of Romania. Farmacia. 2009:57:141-56.

\section{Submit your next manuscript to BioMed Central and we will help you at every step:}

- We accept pre-submission inquiries

- Our selector tool helps you to find the most relevant journal

- We provide round the clock customer support

- Convenient online submission

- Thorough peer review

- Inclusion in PubMed and all major indexing services

- Maximum visibility for your research

Submit your manuscript at www.biomedcentral.com/submit 